\title{
La Academia como recurso articulador: sonetos y villancicos para dos fiestas granadinas (1661 y 1664)
}

\author{
Inmaculada Osuna \\ Universidad Complutense de Madrid*
}

\section{RESUMEN}

Las primeras academias de ocasión impresas en Granada se publicaron entre 1661 y 1664. Por esos años, el concepto de academia aparece en dos pliegos relativos a fiestas granadinas para reforzar la cohesión de poemas escritos para las celebraciones. El primero describe el ornato de la plaza de Bib-Rambla para las fiestas del Corpus de 1661, ocasión en que varios autores fueron invitados a componer poemas sobre los motivos bíblicos y eucarísticos exhibidos en nueve lienzos. El segundo es un pliego de villancicos de Navidad, de 1664, para la Catedral. El artículo analiza los modos en que se transpone a tan inusuales contextos la estructura y hábitos de las academias literarias, e incluye edición de ambos pliegos.

Palabras clave: Poesía, Academias, Barroco, Villancicos, Corpus Christi, Granada.

\section{The Academie as a cohesive resource: sonnets and villancicos for two religious feasts in Granada $(1661,1664)$}

\begin{abstract}
The first transcriptions of occasional academies printed in Granada were published between 1661 and 1664. The concept «academy» also appeared in two contemporary booklets related to feast days; their purpose was likely to reinforce the cohesion of some of the poems composed for each celebration. The first one describes the ornamentation of Bib-Rambla during the 1661 Corpus Christi Feast; at that occasion, several authors were invited to write poems explaining the Biblical and Eucharistic figures represented in nine canvases. The second one contains villancicos to be sung at the Cathedral of Granada on the 1664 Christmas Eve. The article analyzes the different ways in which the structure and habits of literary academies were transposed to these unusual contexts. It also features an edition of both booklets.
\end{abstract}

Key words: Poetry, Academies, Baroque, Villancicos, Corpus Christi, Granada.

" La versión inicial de este trabajo se expuso en el III Taller de Investigación sobre Poesía del Siglo de Oro (Lyra sacra. Poesía religiosa del Siglo de Oro), celebrado en la Universidad Complutense bajo la coordinación de Jesús Ponce y Alain Bègue, a quienes agradezco su invitación a participar en la iniciativa. 
Numerosos impresos granadinos del siglo XVII reflejaron, con variable detenimiento, celebraciones festivas o luctuosas de la ciudad de índole extraordinaria: beatificaciones y canonizaciones de santos, honras reales, inauguraciones de capillas o templos nuevos... Las fiestas periódicas, aun con su intrínseca ruptura con la cotidianidad, fueron menos fructíferas en tal sentido, quizás por su reiteración anual, que en buena medida limaba el halo de excepcionalidad que hacía a otras celebraciones dignas de ser fijadas por escrito y, más aún, impresas en pro de la memoria colectiva. Con todo, algunas fiestas litúrgicas, aun dentro de su anual identidad ritual, conllevaron componentes variables y más «creativos» que, en ciertos momentos, y a veces con miras pragmáticas, pudieron considerarse merecedores de al menos algún impreso menor que diera cuenta de ellos.

En tal contexto se sitúan los dos pliegos que abordaré aquí, en cuarto y de solo cuatro hojas. El primero remite a las fiestas del Corpus Christi de 1661: Salvador de Morales, Adorno de la Plaza de Vivarrambla en el día que... Granada celebra su fiesta al Santísimo Sacramento, con la explicación de pinturas, alegorías y versos (Granada: Imprenta Real, por Francisco Sánchez, 1661). El segundo recoge los villancicos de la Navidad de 1664: Luis de Garay, Villancicos que se han de cantar en la Santa Iglesia Apostólica y Metropolitana de Granada, en los Maitines del Nacimiento de N. S. Jesucristo (Granada: Imprenta Real de Baltasar de Bolíbar, [1664]) ${ }^{1}$.

Ambos pertenecen a una tradición editorial bien documentada en el siglo XVII. La publicación de pliegos con los villancicos que iban a cantarse o se habían cantado en los maitines de Navidad o en la noche de Reyes tuvo extraordinaria amplitud geográfica y cronológica ${ }^{2}$. Para Granada, los pliegos localizados dan cuenta de su regularidad desde al menos 1662, aunque se conservan algunos, más dispersos, de los años cuarenta y cincuenta ${ }^{3}$. La situación parece ser muy distinta para los pliegos sobre los festejos del Corpus. En ámbito nacional, su extensión editorial no parece muy vigorosa. En Granada, en cuanto a impresos poéticos o con al menos algunos versos intercalados, se contabilizan poco más de una docena, número mucho menor que el de pliegos de villancicos. Su cronología es, asimismo, más restringida: aunque se conserva algún pliego anterior (Fernández Solana, 1647), los otros

${ }^{1}$ Del primero, utilizo ejemplares de la Biblioteca del Instituto Jaume Balmes, Barcelona, en depósito en la Universidad Pompeu Fabra, R568(5), y de la Biblioteca de la Fundación Bartolomé March, Palma de Mallorca, olim 67-9-34 (10). Del segundo, el R/34987(2)1, BNE; hay también ejemplar con los mismos textos y variante en la portada: Villancicos que se cantaron..., VE 92-21 (5), BNE; con ese mismo título hay copia manuscrita, sin nombre de autor ni dedicatoria, en ms. 12.954/18 BNE, f. 1r-11r.

${ }^{2}$ Dan idea de ello catálogos como Ruiz de Elvira (1992); Torrente / Marín (2000); GarcíaPlaza (2002); Torrente / Hathaway (2007).

${ }^{3}$ Puede verse, fundamentalmente, López-Huertas Pérez (1997); para los villancicos de la Capilla Real, hay antología y estudio de Tejerizo Robles (1989). 
localizados se limitan, para el siglo XVII, al período comprendido entre 1660 y 1679. Por lo demás, su contenido y presentación editorial muestran menor uniformidad que las publicaciones de villancicos. En términos generales, puede distinguirse entre descripciones en prosa, básicamente informativas, y con poemas expuestos en altares efímeros, y relaciones en verso, a las que cabe atribuir una intención y elaboración «artística» de partida, aunque a veces tengan fuerte componente informativo, y aun prosaico, con frecuencia orientado al panegírico de los comisarios de la fiesta; entre esas últimas se hallan composiciones de autores destacados en el contexto granadino, como Francisco de Trillo y Figueroa, Juan Antonio de la Vella o Antonio López de Mendoza (Trillo, [1661]; Vella, [1661]; Trillo, 1672; López de Mendoza, [1679]).

Entre estos impresos relacionados con sendas fiestas litúrgicas, los dos seleccionados cuentan con otro curioso elemento común, este de índole formal: el uso del concepto de academia como recurso articulador que da coherencia al conjunto de composiciones que se integran en el acto o espacio festivos (los maitines y la decoración efímera de la plaza, respectivamente); a ello se suma la notable proximidad temporal entre ambos.

En este aspecto, se trata de dos muestras aparentemente aisladas dentro de sus respectivas tradiciones compositivas; matizaré después en cada caso, pero, en general, cabe afirmar que no era muy frecuente superponer un elemento de coherencia externa tan evidente a lo que ya tenía unidad temática y espacial o temporal suficiente. Además, se hallan relacionadas desde el punto de vista formal y cronológico con otro fenómeno poético no específicamente - ni siquiera especialmente - religioso: la celebración de academias poéticas y su llamativo acceso a la imprenta en la segunda mitad del siglo XVII (Carrasco Urgoiti, 1965; Bègue, 2007). De hecho, uno de los pliegos se sitúa en esa particular «periferia» de las academias que reflejan ciertos materiales impresos, los cuales, pese a no considerarse convencionalmente como trascripción de una academia o sesión de la misma, de algún modo delatan procedimientos académicos y aun concretas formaciones de tal índole. En esta línea, el uso del concepto de academia en ambos pliegos, aunque con implicaciones en parte distintas, obliga a plantearse el grado de proyección pública, y sus consiguientes condiciones de transposición, de lo que fue una actividad desarrollada casi siempre en ámbito privado.

La conexión más inmediata con la concreción histórica de las academias poéticas granadinas la presenta el pliego sobre el Adorno de la Plaza de Vivarrambla para las fiestas del Corpus de 1661, una descripción en prosa escrita por el presbítero Salvador de Morales, aquí ceñida al programa iconográfico, con los correspondientes poemas, de la plaza granadina más emblemática en las celebraciones festivas. El autor también sacó a la luz pliegos relativos a las fiestas del Corpus de 1660, 1662, 1665 y 1666 (Morales, 1660, 1662, 1664, 1665a, 1665b, y [1666]), sin que haya que descartar, dada la vulnerabilidad de tales impresos, que publicara otros hoy perdidos. De hecho, no faltan va- 
gos indicios. En uno de 1665 declara: «habrá tres años que di las trazas y pensamientos de los altares (como en los demás lo he hecho); han echado fama que los de este año son los mismos. Aquellos hice imprimir, ellos hablarán» (1665b: h. 1r). La cita documenta uno de tantos casos en los que el autor de la descripción coincide con el del trazado de las arquitecturas y decoraciones efímeras y el programa iconográfico; pero además revela el carácter habitual de tal comisión y, por supuesto, el «aire de familia» que impregnaba los textos, hasta el punto de parecer, con las imprecisiones de la memoria, idénticos. La remisión a tres años atrás, si no es aproximada, apuntaría a uno de los impresos conocidos. Por otra parte, en el primero de la citada serie, el de 1660, el autor se lamenta de las limitaciones de espacio: «Mas ya que a un solo pliego la impresión me limita (queja ordinaria, pero no admitida), esta descripción reduciré a un breve epílogo» (1665b: h. 1r). Lamentos de tal índole eran frecuentes entre los tópicos de inefabilidad recurrentes en descripciones de fiestas; sin embargo, la precisión con que Morales menciona la extensión máxima permite la hipótesis de que esa «queja ordinaria, pero no admitida» no sea sino referida a ocasiones similares vividas por el propio autor, con la consiguiente posibilidad de descripciones anteriores hoy desconocidas.

Sea como fuere, no se trató de un lamento meramente tópico. Los pliegos de este autor muestran la complementariedad establecida, al menos algunos años, entre dos pliegos independientes de contenido algo distinto, como refleja su formulación del título; para 1661 y 1665 se conocen ambos pliegos ${ }^{4}$. Los rotulados Descripción de la fiesta y de los altares... mantienen cierta vocación totalizadora: se dedican en su mayoría a los altares erigidos en BibRambla, Plaza Nueva, Pilar del Toro y Plaza de la Pescadería, aunque luego haya breve alusión a otros aspectos de la fiesta como la tarasca, las danzas y gigantes, etc. Por su parte, los titulados Adorno de la plaza de Vivarrambla traducen en términos de autonomía editorial el estatus preeminente de dicha plaza en las fiestas y la consiguiente relevancia del programa iconográfico ideado para ella.

No consta que Salvador de Morales participara en los círculos poéticos de Granada. Aparte de algunos poemas que tuvo que componer para las fiestas del Corpus, consignados en los respectivos pliegos como parte del adorno efímero, ninguno más se halla en impresos granadinos ${ }^{5}$. Sin embargo, en el Adorno... de 1661, al introducir sin necesidad funcional el artificio de la arti-

\footnotetext{
${ }^{4}$ Aparte de los relativos a 1665, citados arriba, y el abordado aquí, está también Morales $(1661)$.

${ }^{5} \mathrm{Me}$ baso fundamentalmente en los detallados índices de López-Huertas, 1997. Un licenciado Salvador de Morales escribe un poema laudatorio para los preliminares de un sermón publicado en 1636 (López-Huertas, 1997: n 15); dada la distancia cronológica, haría falta una indagación biográfica más completa para establecer su identidad.
} 
culación académica, el autor muestra una sensibilidad hacia el prestigio de la práctica poética en la ciudad que sobrepasa lo meramente «utilitario» de unos versos que «declaran» o «explican» imágenes de la decoración. No deja de ser curioso que, años más tarde, en 1664, pese al breve espacio al que Morales debe reducir su descripción, dedique varias líneas de la introducción a elogiar el mérito de los hijos de la ciudad, resaltando - aun sin olvidar las armas - sus cualidades en cuanto a letras y artes. Por el contexto y la posible motivación del elogio, quizás no extrañe que esas cualidades sean vistas no como un valor privado o semi-privado de formación y realización personal, sino en tanto que aportación colectiva a actos de proyección pública; lo que sí resulta más peculiar es que, con respecto a estos, la mención no incida tanto en su vertiente devota, como en su modalidad de producción, que resalta la vertiente intelectual o literaria de la participación:

Esta ciudad de Granada con justa razón puede tenerse por feliz, por verse ilustrada con hijos tan aventajados en las letras, tan famosos en las armas y de tanto lucimiento en todo género de artes y habilidades, sin tener que solicitar extraños sujetos para sus actos públicos en todo género de letras, para sus inventivas, academias, certámenes y obras, que son partos de lucidos ingenios. (Adorno, 1664, f. 1r).

En 1661 el adorno de la plaza principal estuvo articulado en torno a nueve lienzos 6 , cada uno con un episodio del Antiguo Testamento, del que se extraía una alegoría aplicada al Santísimo Sacramento; la imagen se acompañaba de un poema que aludía a la escena bíblica y declaraba la alegoría. En cuanto a la complementariedad de pintura y poesía y a la relación alegórica, o prefiguración, entre situaciones, personajes y conceptos de ambos Testamentos - es decir, del mundo judaico y el cristiano, en inequívoca subordinación del primero al último-, tal planteamiento resultaba bastante común en arquitecturas efímeras. Lo peculiar aquí es el modo en que no solo se resuelve la comisión del material poético sino también su presentación —al menos de cara a la publicación, aunque quizás también se reflejara en la exhibición mural—, como explica el autor al inicio: «En forma de academia dispuse las poesías, repartiendo nueve asuntos a otros tantos ingenios, hijos de esta ciudad, y muy favorecidos de las musas, como en tantos actos lo publican sus acreditados lucimientos» (h. 1r).

Aunque menos explícitamente que en el pasaje de 1664 visto, la cita refleja idénticos focos de interés: orgullo ciudadano concretado en los «hijos» ilustres de la ciudad — aun en sentido lato, como sucede con los hermanos

\footnotetext{
${ }^{6}$ «En nueve lienzos, donde habló sin duda / con elegancia la poesía muda, / de Ambrosio se admiró la diestra mano, / que es de estos siglos el segundo Cano, / y de Atanasio y Cieza los pinceles, / Timantes uno y otro Praxiteles» (Vella, 1661: f. 4v); «Del culto Ambrosio (Apeles castellano) / obra elegante, heroico pensamiento / del Maestro Morales [...]». (Trillo, [1661]: f. 2r; publicó el poema Gallego Morell en Trillo, 1951: 387-395). Miguel Garrido Atienza identifica al pintor con el también poeta Ambrosio Martínez de Bustos (1990: 55).
} 
Trillo y Figueroa, avecindados desde niños pero no nacidos en Granada- y lucimiento público de sus dotes literarias. Pero sobre todo destaca el aprecio de la modalidad de producción que entraña la academia. En un impreso análogo de 1665, Morales indica que los poemas han sido escritos por «un sujeto docto de esta ciudad» (1665a: h. 1r), sin desvelar su nombre y respetando así una práctica algo frecuente en la poesía religiosa pública: el anonimato como signo de humildad, en muestra de que lo importante no era la gloria del poeta sino el fin devoto. Aquí, en cambio, se pasa al otro extremo, al de la academia como espacio del orgullo autorial, reforzado por la pertenencia a un grupo de connotaciones elitistas, al menos en lo intelectual o literario. $\mathrm{Y}$ es que el procedimiento que sigue Morales, con su precisa caracterización «en forma de academia», implica mucho más que un simple apartarse de lo posiblemente usual - que una persona, el comisionado para la traza de la decoración efímera o alguien en quien él delegara, escribiera toda la serie de poemas-, al distribuir, como si de mero expediente cómodo se tratase, la tarea entre varios ingenios. Por el contrario, los elementos que toma del funcionamiento de una academia confirman un proceder bastante consciente y elaborado.

En primer lugar y de forma destacada, uno de esos elementos es justo el reparto de asuntos, término propio de academias y certámenes que el autor se cuida de incluir en su impreso, rotulando así la sección de poemas de encargo. En efecto, frente al certamen o justa poética, lo más común de las academias fue el reparto unipersonal de asuntos entre sus componentes, y no la abierta competencia de estos a cualquier tema propuesto. Lo que calla Salvador de Morales es el grado de precisión de su encargo. Lógicamente, este incluiría la adjudicación de cada episodio bíblico, pero no debió de ser el único pie forzado. El metro tuvo que ser otro: no todos los ingenios coincidirían en contribuir con un soneto por azar. Sin duda, la gama métrica de la poesía mural tendía a ser limitada: aun no siendo imprescindible, la brevedad facilitaba una lectura condicionada por el espacio y, previsiblemente, por circunstancias de escasa concentración mental y privacidad; sin embargo, tal gama era variada, desde combinaciones raras en otros contextos, como el tercetillo, hasta la octava o el soneto, de carácter polivalente. Más difícil es discernir si la petición incluyó orientaciones sobre la estructura interna de los poemas. Salvo en los dos primeros, la articulación del soneto se aprovecha de modo que los cuartetos se dedican a la historia bíblica y los tercetos a la alegoría sacramental, pero esa coincidencia pudo ser casual.

Los otros elementos destacados que refleja Salvador de Morales remiten a la peculiar estructura celebrativa de las academias. Los respectivos contextos eran de características opuestas. La sesión académica tenía lugar en un espacio privado y su ceremonial se desarrollaba en el tiempo. En cambio, el adorno de la plaza se destinaba a un ámbito público, y la recepción de los poemas no dependía tanto de una secuencia temporal como de su distribución 
espacial; de hecho, no consta si el público que accedía a la plaza tenía un itinerario que pautara la lectura, si bien las historias sí aparecen en el pliego según un orden, el de los libros bíblicos que las refieren.

Pese a esas diferencias, aparecen aquí elementos propios del ceremonial de las academias, con sus mecanismos de apertura, engarce y cierre, con frecuencia documentados en impresos que divulgaron sesiones de carácter extraordinario. Tales mecanismos pudieron variar de unas formaciones a otras, y aun es posible que se crearan usos locales distintivos en cuanto a la presencia o no de la figura del fiscal, la posición del vejamen, etc. Para Granada, en el siglo XVII, se conocen ocho impresos explícitamente ligados a la celebración de academias —en principio, de ocasión-, que se concentran entre 1661 y 1685 (Osuna, 2004a). Obviando algunas excepciones, su estructura-tipo podría resumirse en lo siguiente: 1) una introducción del presidente, en verso y combinada con partes musicadas, que asume la convocatoria de los ingenios; 2) una intervención del secretario en prosa, hilo conductor donde se engarzan los composiciones presentadas, con frecuente tono de vejamen, junto con unos versos festivos tras cada poema (a veces el vejamen se elude con alguna justificación, o se desvía hacia figuras distintas de los participantes, pero parece haberse considerado inherente a estos actos); y 3) cierre encomiástico o Laudatoria, casi siempre en verso.

Como reflejo de esa estructura, Salvador de Morales elabora sendos sonetos de apertura y cierre. Por desgracia, no explicita si estuvieron expuestos en la plaza o bien se compusieron para el impreso a fin de reforzar el artificio constructivo concebido aquel año para el adorno de la plaza. El primero cumple la función de convocatoria de los ingenios y proposición genérica del tema, y al asumir Morales su autoría, se adjudica implícitamente el papel de presidente de tan peculiar academia. En este soneto, junto con la finalidad fática de la invocación, la tópica laudatoria activa motivos usuales en la introducción de academias y justas, con el léxico ennoblecedor de raigambre clasicista en el que los poetas se ven reconocidos («cisnes», «acentos», «armonía», «del oído lisonja», «suspenso... el castalio coro») y la complacencia en el vínculo con la ciudad, también en idealizada metonimia representada por sus ríos, Genil y Dauro. No falta, sin embargo, la concreción contextual. La complementariedad de poemas y cuadros ocupa parte de los tercetos: «Del sacro texto os propongo asuntos / [...] / que diestra mano copia sus trasuntos / en lienzos que realzan los colores» (h. 1v). Y aún más concretos resultan los dos versos finales: «Cantad, pues celebráis con dulces puntos / a un Sol que oculta en nubes resplandores» (ibid.). La perifrástica y un tanto enigmática referencia a Cristo sacramentado reproduce una de las tradicionales imágenes teológicas para la explicación del misterio ${ }^{7}$. Sin embargo, ni siquiera

\footnotetext{
${ }^{7}$ Cf., por ejemplo, en referencia a Ez 32, «Sole nube tegam»: «Deus olim se Ezechieli nubi cuidam inuolutum ostendit, ad eum fere modum, quo postea hisce nostris temporibus
} 
haría falta estar familiarizado con tal simbología para descubrir, más allá de su alusión a conceptos de abstracto bagaje teológico, elementos visuales de la fiesta: como era costumbre, un carro triunfal aumentaba la vistosidad de la procesión, y ese año, según lo describe Francisco de Trillo y Figueroa, «en él Ceres y Baco en sombra ofrece / (siguiendo a un Sol) un Dios Sacramentado» (Trillo, 1661: f. 2r). Así lo detalla Salvador de Morales en la complementaria Descripción de la fiesta y los altares de ese año:

En este [carro], pues, luciente, como majestuoso, se ve en la parte superior triunfando un sol, que en medio de sus dorados rayos se retrata un cáliz y una hostia. A quien, un poco más abajo, le asisten dos hermosos niños abrazados, que representando [sic] el signo de Géminis (signo que significa amor, y juntamente hoy diez y seis de junio, día en que se celebra aquella fiesta, en este signo reina el Sol). La diosa Ceres, coronada de espigas, y el dios Baco, de pámpanos y racimos, van sentados en dos triunfales sillas, a los cuales la ciega antigüedad veneró por inventores del pan y del vino. Todo lo cual es una hermosa alegoría en que se da a entender que el divino y soberano Sol de justicia, Cristo, Señor Nuestro, quedándose sacramentado debajo de las especies de pan y vino, recibiéndole el hombre dignamente, se une con él con estrechos y amorosos lazos [...]. Siete dioses de la antiguiedad van delante festejando a aqueste Sol, tan gigantes en las galas que son de los vistosos que han salido, cuyos trajes, motes y cifras descubren las finezas de tan divino Sol en nubes de accidentes disfrazado, como lo dicen los tercetos que con letras de oro van grabados en los escudos que llevan embrazados. (h. $2 \mathrm{v}$ ).

Por su parte, el soneto de cierre cumple con puntualidad la función de la Laudatoria académica. Como si a una secuencia temporal se refiriese, marca el final de las intervenciones («cantado habéis») e incluye términos de valoración positiva («dulcemente», «habéis juntado / lo agudo con lo grave y elocuente»). Tampoco falta la alusión al merecimiento de premio: un galardón poético que, en común hipérbole laudatoria, no es un laurel cualquiera, sino el del mismo Apolo, pero también un premio espiritual («No vuestro premio se verá inconstante / si cultos dais a una beldad sagrada»), no «inconstante», quizás en contraposición implícita con el mundano premio poético. A ello se suma, muy de pasada, la identificación de la ciudad que sirve de escenario, con el ya tópico juego de palabras a partir de la dilogía de Granada y la metáfora de sus habitantes como granos, que a su vez son rubíes («Bellos rubíes sois de esta Granada») ${ }^{8}$.

Por el contrario, están ausentes los elementos de conexión entre los poemas — salvo la implícita progresión de los episodios según el orden bíblico-

sub accidentium Sacramentalium nube latet» (Lohner, 1698: 348, s. v. Communio). Sin expresa remisión bíblica, también: «Pondera tú, que has de hospedar hoy, no la sombra, sino el Sol mismo, aunque dentro de la nube de los accidentes; no ya la figura, sino la realidad de un Dios real y verdaderamente encerrado en esta hostia [...]». (Gracián, 2001: 1530).

${ }^{8}$ Baste recordar el romance de Góngora, de 1611, «Cloris, el más bello grano, / si no el más dulce rubí / de la Granada, a quien lame / sus cáscaras el Genil». 
y el vejamen, que, como se ha indicado, en las academias granadinas de la época solía estar intercalado y, por tanto, cubría tal función. De hecho, solo dos de las ocho academias impresas acusan la falta, formal o de sentido, de vejamen: en la celebrada en 1664 en honor del Duque de Alburquerque, su ausencia se siente necesitada de justificación, en ese caso el alto asunto celebrado, que no hace merecedores de censura a poetas que tan bien han empleado su esfuerzo; en la de 1662, sobre la Inmaculada Concepción, el vejamen acaba recayendo no en los poetas participantes, sino en los de la corte de Apolo. Posiblemente en el pliego del Corpus subyace un motivo similar. En general hay un abandono de lo burlesco. En la trilogía principal de valoraciones que contiene el soneto de cierre («agudo», «grave», «elocuente») no falta un parámetro, el de la agudeza, cuya amplitud de sentido no evita que, a estas alturas de siglo, suela percibirse como próximo a la ingeniosidad burlesca; aquí, sin embargo, lo «agudo» de los poemas tiene que referirse a otro ámbito, el de las asociaciones alegóricas, que requieren descubrir el misterio que entraña la figura bíblica. Tal abandono podría parecer obvio, pero a tenor del uso (controlado) del vejamen en otros contextos religiosos, resulta significativo.

Por último, también se refleja en el impreso otro elemento frecuente en el funcionamiento de las academias, un tanto anecdótico: la presencia de algún poema que responde a alguno de los asuntos propuestos, pero aparentemente compuesto fuera del regular reparto unipersonal. Así, tras el cierre formal con el soneto de Salvador de Morales, otro de don Sancho de Guzmán Portocarrero vuelve a tratar el cuarto asunto de la «academia» ${ }^{9}$. Los motivos de su inclusión, como en casos análogos de academias coetáneas, se quedan en el campo de las hipótesis: quizás se debiera a una iniciativa personal del poeta, que Salvador de Morales, como encargado de la publicación, tuviera que aceptar por amistad o compromiso, o bien pudo ser iniciativa del propio promotor hacia alguien a quien quisiera distinguir entre los participantes, dándole libertad para elegir entre los asuntos propuestos. Ambos supuestos no desdicen, en todo caso, de su conformidad con los usos académicos.

Así pues, a lo largo del pliego se hace evidente que Salvador de Morales extrajo con conocimiento y precisión prácticas usuales en las academias, desde el mero reparto de asuntos a los elementos de la estructura ceremonial de su celebración, sin olvidar presuntas irregularidades como la ocasional intervención al margen —al menos en apariencia — de la organización inicial. Pero

${ }^{9}$ Sancho de Guzmán Portocarrero (o en un impreso anterior, Guzmán Sarabia), era tío del poeta malagueño Juan de Ovando y Santarén y, según consta en algunas de sus publicaciones, Caballero del Orden de San Juan y Capellán de Honor en la Capilla Real de Granada (en un par de impresos también figura como «Limosnero del Infante Sr. D. Juan de Austria»). Compuso varios poemas laudatorios de carácter nobiliario, entre ellos un panegírico a uno de los comisarios de las fiestas del Corpus de 1664; escribió asimismo un poema por la traslación del cuerpo de San Juan de Dios (1664). 
quizás fue aún más allá, acudiendo a las mismas personas que participaban en alguna academia o academias en la ciudad.

Este impreso — como el de villancicos que abordaré después- sale a la luz cuando está aflorando en el mercado editorial granadino el fenómeno académico. Justo entre 1661 y 1664 se publican cuatro academias de ocasión; además, las recurrencias parciales de participantes en ellas podrían estar delatando la existencia de una academia periódica con un núcleo de miembros más o menos estable, al cual circunstancialmente se añadirían, o restarían, algunos (Álvarez / García Aguilar / Osuna, 2008: II, 323-327 y 333-336). En este impreso del Corpus el número de poetas es bastante más reducido, y por tanto difícilmente podría reflejar una academia completa del momento; sin embargo, hay datos suficientemente significativos.

Excluyendo a Salvador de Morales, responsable por instancias institucionales del adorno de las fiestas, y a Sancho de Guzmán, con su poema «extraacadémico», tenemos nueve autores: todos menos dos (Laureano Antonio de Morales y Félix de Sandoval) participan en alguna de esas cuatro academias impresas; de ellos, uno (Fernando de Carvajal y Pacheco) aparece solo en una, pero cuatro (Gaspar Afán de Ribera, Nicolás de Cervantes, Sebastián Antonio de Gadea y Juan de Trillo) están presentes en tres o cuatro, en lo que podría considerarse, con los datos disponibles, como una participación muy regular. Y varios de ellos intervienen también en algunas justas poéticas de la ciudad, aunque no lo hacen de manera tan mayoritaria ni regular como en las academias ${ }^{10}$.

El proceder de Salvador de Morales en la elección de estos ingenios plantea, pues, el difuso límite entre academias reales y academias ficticias, y lo hace desde una perspectiva distinta de las que a veces han marcado la aproximación a este aspecto, con la reutilización de materiales académicos intercalándolos en obras en prosa o con la invención o recreación novelesca de reuniones de tal índole (King, 1967; Sánchez, 1961: 167-192, 231-232, 287-289, 292-293; Mas i Usó, 1996, pp. 67-71). Aquí hallamos procedimientos de academia y autores posiblemente familiarizados con tales prácticas, pero todo ello está destinado a un contexto público y ceremonial distinto. Menos definitorio en cuanto a las diferencias es que el tema sea religioso. Aunque la mayoría de las academias de ocasión granadinas reconocidas como tales son de tema profano, en 1662, con motivo de un breve papal sobre la Inmaculada Concepción, se celebra una en el contexto de las fiestas ciudadanas y en las mismas

${ }^{10}$ En un certamen sobre la Inmaculada Concepción convocado por la Hermandad de Escribanos Reales en 1662 ó 1663 intervinieron Nicolás de Cervantes, Sebastián Antonio de Gadea, Juan y Francisco de Trillo y Figueroa. Laureano de Morales y Francisco de Trillo habían participado en otro certamen de tema inmaculista, en 1650; Juan Rubio de la Fuente, lo hará, décadas después, en el dedicado a la canonización de San Juan de Dios, de 1691 (Osuna, 2004b: 64, 68 y 75). 
dependencias del convento que promovió los festejos, proporcionando así otro curioso ejemplo de trasvase público de la actividad privada de la academia (Cervantes Ervías, 1662). Sin embargo, si en ella su desarrollo no sufre ulteriores adaptaciones, como lo demuestra su semejanza con otras academias de ocasión en casas particulares, en la iniciativa de Salvador de Morales sí son evidentes las divergencias con respecto a ese «modelo», ya que, aparte de un criterio presuntamente más selectivo en cuanto a participación, la presentación final de los resultados no se amolda al uso común. Por otra parte, sería difícil decantarse por la calificación de «academia ficticia» cuando hay un reparto real de asuntos entre ingenios, aunque, al mismo tiempo, la concepción del conjunto como academia no deja de ser sino un artificio para el que resulta irrelevante la celebración efectiva o no de ella según las pautas habituales, con su lectura colectiva de los poemas y un desarrollo temporal donde los sonetos de apertura y cierre cobraran - y no solo simularan - todo su sentido ceremonial.

A pesar de su común referencia, muy distinto es el uso del concepto de academia en el pliego de villancicos navideños de 1664. Como se ha visto, tal concepto alcanzaba notable concreción fáctica en el Adorno de la plaza de Vivarrambla: generaba poemas expresamente elaborados para la fiesta, con un diseño coherente del conjunto y una autoría que remitía a personas del entorno de los receptores originales. Los villancicos del pliego, en cambio, carecen de concreción espacial y cronológica, así como de indicaciones de autor; además, exceptuando el primero y el último, pertenecen a una variedad de subgéneros análoga a la de otras series de villancicos para iguales o similares celebraciones, y no tuvieron por qué ser compuestos para esa ocasión, sin que pueda descartarse, según prácticas habituales de la época, la reutilización de textos anteriores, aun de otras ciudades. En general, la impresión de conjunto es que simplemente se recurrió a un «estereotipo» del concepto de academia, lo cual es bastante coherente con los recursos creativos del villancico religioso del momento, tan afecto a clichés lingüísticos y genéricos.

Con respecto a los villancicos del pliego, ni del primero (Convocatoria) ni del último (Vejamen) consta que se cantaran, antes o después, en otras fiestas navideñas ${ }^{11}$. De algunos de los otros seis villancicos sí hay evidencias, hasta ahora todas posteriores. El titulado como Asunto III tiene coincidencias parciales con el Villancico IV cantado en Alcalá en 1666, también en maitines de Navidad (Villancicos, [1666]): ambos comparten la introducción y el estribillo, pero las coplas son distintas. El rotulado como Asunto $V$ se cantó en el mismo lugar y ocasión, en este caso con coincidencia textual en la mayor parte de la introducción, y básicamente con las mismas coplas, aunque se registran algunos cambios de orden, la supresión y adición de algunas quintillas y otras variantes menores. El aquí llamado Asunto IV aparece, sin variantes

${ }^{11}$ Aparte de los catálogos citados en la nota 2, tengo en cuenta también Laird ([2008]). 
significativas, entre los cantados en la Navidad de 1694 en Lucena (Letras, [1694] $)^{12}$. Así pues, aunque con los datos disponibles no consta que los seis villancicos intermedios hubieran tenido difusión anterior, no queda duda de que podían ser utilizados por separado sin necesidad de reajustes fuera del marco académico que aquí se le superpone.

Pese a todo, como en el pliego de Salvador de Morales, la coincidencia temporal con el fenómeno real de los impresos académicos granadinos parece significativa, por más que aquí se trate casi con toda probabilidad de una «academia» ficticia. Al fin y al cabo, como ocurre en otros contextos para la consecución de efectos ingeniosos análogos, este artificio articulador en la serie de villancicos debía de fundarse en la posibilidad de que los receptores reconocieran concomitancias con las academias reales.

El procedimiento resulta bastante peculiar: normalmente el tema navideño y el propio contexto litúrgico aportaban una coherencia temática suficiente. No obedecía, pues, a una necesidad inherente al género o al contexto que los villancicos estuvieran cohesionados —al menos en teoría- gracias a un marco conceptual global. Existen ejemplos análogos aislados ${ }^{13}$; sin embargo, lo más común era que la secuencia de villancicos careciera de elementos de cohesión intertextual. Con todo, el recurso estaba relacionado con otras manifestaciones literarias y artísticas de la fiesta religiosa: algunas pretensiones de presentación unitaria superpuesta al tema principal de la fiesta pueden verse en programas iconográficos de arquitecturas efímeras y también en algunas justas religiosas donde, aparte de la coherencia en torno al santo o motivo celebrado, los requerimientos métricos y temáticos se relacionan con una serie coherente de elementos (los siete planetas, mujeres bíblicas, etc.). Además, el procedimiento se revela en cierto modo como derivación de los juegos conceptuales y metáforas ingeniosas del llamado «conceptismo sacro»; por utilizar una imagen común en los rótulos de poemas, lo que hallamos aquí es una serie de villancicos «en metáfora de» academia $^{14}$.

${ }^{12}$ Edita el pliego Cruz Casado (2004: 91-125, el poema en 104-106).

${ }^{13}$ Alguno resulta bastante próximo en su inspiración. En Letras, [¿1695?] (R/34986(17) BNE), salvo el villancico inicial, para la Kalenda, el resto se articula como proposición de un certamen poético y los asuntos resultantes; la portada indica que Melchor de Santos compuso las letras y «las ha puesto también en música». En Villancicos, [1684] (R/34989(17) BNE), aparecen varios agrupados en torno a la supuesta celebración de una academia, pero se corresponden solo con el segundo nocturno, mientras que los restantes villancicos acuden a otros motivos. Pueden citarse, además, dos pliegos toledanos con un plan compositivo semejante: en el primero un villancico introductorio alude a las siete artes liberales, a las que se dedican, respectivamente, los siete villancicos restantes (Letras, [1666], VE 88-31 BNE); en el segundo se hace lo mismo con las artes mecánicas, con explícita referencia al inicio del primer villancico al artificio de la Navidad anterior (Letras, [1667], VE 88-32 BNE). Ambas series de villancicos están recogidas entre las obras póstumas de Manuel de León Marchante (1733: 31-49).

${ }^{14}$ De hecho, utiliza esa expresión la rúbrica del primer villancico del segundo nocturno en el pliego madrileño de 1684 citado (también en Pérez de Montoro, 1736: II, 404-415). 
La articulación está marcada por la nomenclatura académica típica, que de inmediato destaca en los rótulos de cada villancico del pliego: Convocatoria, Asunto (más el ordinal correspondiente) y Vejamen. La más que probable recepción escrita de los textos, previa o simultánea a su realización musical ${ }^{15}$, garantizaría en buena medida la efectividad de tales paratextos aun en el marco litúrgico para el que los villancicos estaban pensados. Con todo, la modalidad genuina de recepción era oral, y en este sentido debe entenderse la función esencial que cumplen los textos de la Convocatoria y del Vejamen, hasta el punto de que, en su realización musical, sin la función cohesiva de estos dos villancicos, los llamados asuntos no podrían ser identificados como tales.

El villancico que asume la Convocatoria adopta una estructura usual en este género musical: introducción, Estribillo y Coplas. La introducción, desde el primer sintagma, proporciona la clave desde la que hay que interpretar los textos: como academia de ingenios. Con todo, aún se mantiene la duda de si, dada la autonomía de sentido que en su contexto litúrgico suelen tener los villancicos entre sí, esa academia se cerrará con el final de esta primera pieza; hará falta que lleguen las coplas para vislumbrar que la Convocatoria está anunciando también las composiciones venideras. Como en el soneto análogo del pliego sobre las fiestas del Corpus, la introducción se reviste del léxico y tono propios de las convocatorias de justas y academias («laurel», «lid», «corona», «Apolo», «certamen», «aplaudir», «gloria»), pero también actúan los mecanismos de conversión a lo divino, al mencionar al «Apolo divino» ('Cristo') y situar el término «gloria» en un contexto de normal interpretación religiosa; como no podía ser menos, y de nuevo al igual que en el soneto inicial de Salvador de Morales, se marca la supremacía del plano religioso: frente a la «lid» poética, cuya victoria es sancionada por el «laurel», presidirán el encuentro la «oliva» y la «paz», implícitamente asociadas al nacimiento de Cristo, pues el premio no procede de la contienda, sino de la mera participación («un Apolo divino, que os premie / con solo el venir»).

También el estribillo de la Convocatoria conserva aún cierto grado de generalidad: insiste en la convocatoria de los ingenios, aumenta las referencias al tema navideño, proponiéndolo expresamente como objeto de la academia («venid a celebrar / a un Sol que, para nacer, / se nos pone en un portal»), y salpica el texto con un cliché propio de villancicos y otras composiciones musicales («vaya de fiesta, vaya») ${ }^{16}$. Pero además registra la primera mención concreta a los villancicos siguientes, en este caso reducida al vejamen y a su usual mezcla de «veras y chanzas»; como con la posterior dilogía de gracia,

\footnotetext{
${ }^{15}$ Recuérdese la variante de la portada, no inusual en la época, en los testimonios conservados: «villancicos que se cantaron» / «villancicos que se han de cantar» (véase nota 1).

${ }^{16}$ En los villancicos indicaciones similares identifican un preciso subgénero, como la frecuente «vaya de jácara»; hay ejemplos análogos como «vaya de enigma», «vaya de vítor», «vaya de motes»...
} 
posiblemente recoge con ello el especial atractivo, en teoría más «popular», que ejercía el tratamiento burlesco por el que este se caracterizaba. Se hace así evidente ya la contraposición con el sentido de gravedad y elocuencia del otro impreso abordado.

Las coplas, por su parte, sitúan la convocatoria en medio de cierta indefinición entre certamen y academia. Es verdad que el término certamen se documenta en la época aplicado a academias ${ }^{17}$, pero aquí la ambigüedad aumenta con el verbo publicar («Cuyo sagrado certamen / publica la paz mejor / que la lid, pues la Poesía / es toda composición»). La indeterminación también se cierne sobre el reparto de asuntos: junto con expresiones que reflejan la distribución unipersonal habitual en academias («otro ingenio retrate»; «en el cuarto asunto aplauda / la flor que hoy nace otra voz»; «otro ingenio una gaceta / escribirá»), otras desplazan de modo impersonal el enunciado al asunto, sin decantarse por un receptor singular o plural («pinte otro asunto», «el último asunto sea»), mientras que alguna vez se usa un plural indeterminado, más propio de la convocatoria pública de justas que del reparto académico («el primero asunto escriban»). Con todo, aun tratando con laxitud estas oscilaciones, en especial la última, lo cierto es que no se reproduce, aunque fuera con deformación burlesca, el reparto personalizado con nombres concretos, proceder mayoritario en las academias coetáneas que sí tenía reflejo en el pliego de Salvador de Morales. Como en otros aspectos, se hace patente la tendencia hacia el estereotipo y la indefinición en el trasvase de usos académicos.

Desde el punto de vista funcional, lo más característico de estas coplas es la enunciación ordenada y explícita de los asuntos de la academia. Con ello dotan de un supuesto carácter unitario a unos villancicos que, más allá del tema navideño, no lo tenían. En cierto modo, incluso podría decirse que el programa iconográfico de la plaza de Bib-Rambla, totalmente homogéneo en el planteamiento de sus composiciones, es menos fiel que esta otra «academia» a la práctica real que se vislumbra aun en academias de temática unitaria, como suelen ser la mayoría de las de ocasión, también ellas marcadas por la variedad de metros, tonos y subgéneros.

Las coplas de la Convocatoria resaltan la diversidad de procedimientos discursivos de los villancicos siguientes, aunque a veces no ofrecen la auténtica nota característica del poema. Así, cuando en referencia al primer villancico se define el primer asunto («haciendo obrero al Señor / las virtudes, pues es de ellas / propia la edificación»), se aporta la clave de la metáfora «constructora» que provee al poema de términos alusivos constantes, con sus dilogías y juegos de palabras («sólo se paga de buenas obras», «una obra de ley», «levantar la Iglesia», «la más bien unida mezcla», «del tesoro de sus venas»), a veces combinados con imágenes del simbolismo religioso («la entrada por

${ }^{17}$ Por ejemplo, sin salir de Granada, Justa (1674). 
cinco puertas»); sin embargo, esas «virtudes» mentadas — posiblemente solo mero pie para el juego conceptual con «edificación»- no tienen presencia temática propia en el villancico al que se remite. Asimismo, la referencia al segundo asunto como «comisión de regidores» alude a los protagonistas, dos regidores nombrados comisarios de las fiestas por el nacimiento de Cristo, pero lo más característico del poema, aparte de la situación-tipo burlesca de disputa de personajes más o menos pintorescos, es el efecto cómico de dos estereotipos linguiísticos, la fabla antigua del castellano y el español incorrecto, con deformaciones tipificadas, del morisco ${ }^{18}$.

Mejor extraídos están, en cambio, los aspectos definitorios de los siguientes villancicos, de carácter más lírico: la oposición entre la noche y el día del tercer asunto y, en el cuarto, la metáfora de Cristo como flor, combinada con el artificio del uso de ecos, entendiendo por tales la formación de nuevas estrofas con sentido completo a partir de las últimas palabras de cada verso. El muestrario se completa con dos subgéneros burlescos, para los que la rápida caracterización de la Convocatoria podría evocar, con solo nombrarlos, los rasgos usuales: la gaceta y la pandorga. El primero se basa en el rifacimento burlesco de un género popular que, al igual que otros de notable fortuna cómica en villancicos de la época, como las oraciones o el almanaque o calendario, estuvo normalmente asociado a la venta ambulante de los ciegos. A su modo, toma de las gacetas reales su finalidad noticiera, apropiándose del léxico al uso («buenas nuevas», «prodigios», «epístola») y de la retórica y formulismo habituales para la ponderación de la veracidad y de la amplia divulgación de la noticia («dícese... por muy fijo»; «también por cierto ha corrido»); pero a esta apropiación textual añadía, como en los otros contrafacta señalados, los omnipresentes juegos de palabras, que sostenían, más que la transposición navideña misma, la deformación burlesca de la parodia. En el sexto asunto, lo específico de la pandorga ('junta de variedad de instrumentos, de que resulta consonancia de mucho ruido', según Autoridades) se contamina con una ambientación pastoril posiblemente motivada por el tema navideño («mayoral», «zagales», «escribano de aldea»). Con todo, los recursos caracterizadores y la comicidad recaen, al menos en su mayor parte, sobre la presentación de los instrumentos musicales y lo estrafalario de tan peculiar grupo, por más que tampoco falten los juegos de palabras, sobre todo en momentos en que se atenúa esa comicidad situacional resultante de la pandorga, como ocurre en las coplas y en menor medida en la introducción ${ }^{19}$.

${ }^{18}$ Los mismos estereotipos aparecen en el teatro; entre los planteamientos recientes sobre el tema, puede señalarse, por ejemplo, con ajustada remisión bibliográfica, Vesselínova Pavlova, 2004.

${ }^{19}$ El sentido de compensación no es exacto, pero sí significativo: la introducción contiene algunos juegos lingüísticos, entre los que sobresale la absurda sustitución, dilogía mediante, de los protocolos o instrumentos notariales por los musicales; en el estribillo, con una comicidad suficientemente apoyada en las hilarantes onomatopeyas, los juegos de pala- 
El otro villancico con una función específica dentro de la metáfora de academia que cohesiona el conjunto es el último, rotulado como Vejamen. Al igual que la Convocatoria, contiene marcas textuales precisas desde el inicio («Vaya de villancico, / que es el vejamen») y muestra una clara distinción funcional entre introducción y estribillo por un lado, y por otro las coplas. Esas dos primeras secciones recogen tópicos que dan idea del estereotipo de vejamen. Desde el punto de vista funcional, corresponde a este el cierre de la Academia, cometido que no coincide con lo documentado en academias de ocasión impresas en Granada en esos años, aunque sí con un uso común en otras ciudades; en cuanto al contenido, remite a ideas normalmente asociadas al concepto de vejamen: la mezcla de burlas y veras y la pretendida moderada intención de su ataque, que pincha pero no hace sangre ${ }^{20}$.

Las coplas, en cambio, se ocupan sobre todo de una revisión de los asuntos en orden, cumpliendo así una función cohesiva paralela a la de las coplas de la Convocatoria. Antes de entrar en ello, empiezan con una de las pullas más universales contra los poetas: la imagen del poeta pobre y desastrado, aquí aplicada al Niño Jesús, fugazmente convertido en poeta, por desnudo. La inmediata revisión de los asuntos se realiza, como corresponde al vejamen, en clave de indicación de defectos. De nuevo, con trazos esquemáticos, se alude al contenido de cada asunto, con una caracterización coincidente en lo esencial con la de la Convocatoria: la metáfora de Cristo como maestro de obras del primer asunto, los dos regidores del segundo, la contienda entre noche y día del tercero, los ecos y la metáfora de la flor del cuarto, la gaceta del quinto y la pandorga del sexto. Quizás el único en que se seleccionan matices adicionales sea el segundo: si en la Convocatoria se silenciaban los detalles y aun el propio sentido de la contienda entre los dos regidores, en el Vejamen sí se explicita la confrontación religiosa de fondo («tuvisteis fiesta de moros / y cristianos») y lo risible de su actitud («dos regidores vanos»), aunque tampoco aquí se precisa el componente de comicidad lingüística.

Junto a este repaso básicamente argumental, se diseminan términos que pretenden evocar el sentido de «crítica literaria» del vejamen. Sin embargo, fácilmente se ve la subordinación al juego lingüístico y conceptual, en detrimento de un auténtico juicio de los poemas, algo tampoco extraño, aunque con excepciones, en las prácticas académicas coetáneas. De este modo, la dilogía de ripio (aparte de su sentido aplicado a poesía, considérese la acepción de 'fragmentos que quedan de los materiales desechados o quebrados', Autori-

bras disminuyen, reduciéndose a la dilogía de destemplar; los retoman con cierta regularidad las coplas, que, salvo muy vagamente por la idea de «celebrar» una fiesta y por el fragmento de estribillo que repiten, carecen de las referencias musicales relacionadas con la pandorga.

${ }^{20}$ Han abordado detalladamente el género, en diversos contextos y manifestaciones tanto en prosa como en verso, Cara (2001) y Madroñal (2005). 
dades) remite al léxico de la construcción del primer poema; la contraposición entre «montañés jabalí» y «llano lebrel» retoma la oposición entre el hidalgo castellano (montañés, "por antonomasia se entiende el de la Montañas de Burgos', Auts.) y el morisco, pero dejando ahí resonar, sobre todo en el último término, los conceptos de estilo elevado y estilo llano; o de modo semejante, la contraposición noche-día propicia la evocación literaria en la dicotomía estilística claro / oscuro («que aun de día no habla claro / pluma que la luz embarga»). Incluso términos algo menos marcados como «donaire» o «suave» juegan con su eventual empleo para la valoración literaria y a la vez con temas o procedimientos de los respectivos villancicos: el primero a raíz de la mención de los ecos, «cosa de aire», que genera toda una cadena derivativa o pseudoderivativa (aire, desgaire, donaire), el segundo a partir del tópico de la veracidad de la gaceta («que no escribió muy suave, / y es que la verdad amarga»). En todo caso, el salto asociativo de pretensión lúdica, con frecuencia disparatado - y posiblemente ya desgastado por su habitual uso en contextos similares-, queda al margen de una aplicación concreta a las características estilísticas y técnicas de cada villancico.

En definitiva, como se aprecia en este acercamiento a ambos pliegos, los elementos académicos utilizados son solo parcialmente coincidentes, y aun el grado de elaboración con que se procede es muy distinto, desde una transposición, artificial si se quiere, pero bastante ajustada en varios aspectos a la realidad local coetánea, hasta la acomodación a un estereotipo, con la mera articulación que aportan las composiciones de apertura y cierre y apoyándose en el sentido de variedad de las sesiones académicas. En ambos casos, sin embargo, se aprecia el regusto por un componente ingenioso que superponga a la unidad temática de la celebración una unidad constructiva distinta, basada en unos usos sociales que los receptores, para el óptimo rendimiento del proceder, debían estar en condiciones de reconocer. El preciso motivo escogido implica la sintomática proyección pública de una práctica que, en principio, estaba asociada a la esfera de lo privado, a la formación de grupos con connotaciones de pretendida élite literaria o intelectual — cuando no también social— en el ámbito local, lógicamente marcados por un acceso discrecional. Tal proyección y reconocimiento no tendrían por qué identificarse con una «democratización» del fenómeno: la fiesta ciudadana integraba elementos muy heterogéneos en cuanto a la complejidad de su descodificación cultural, y no todos los grupos de potenciales receptores podrían disfrutarlos en la misma medida y hasta sus últimas consecuencias interpretativas. Baste considerar los poemas «bíblicos» compuestos para la iniciativa de Salvador de Morales, que no son precisamente un ejemplo de catequesis básica sobre la Eucaristía; o pensar en las condiciones de recepción oral de los villancicos en la catedral granadina. Con todo, dicha proyección ciudadana resulta un modesto — por ocasional — síntoma paralelo de los cambios de mentalidad, apreciación o gusto que debieron de subyacer al hecho de que las academias, durante tanto tiempo celadas entre salones privados y restringida 
difusión manuscrita, ya por estos años salieran ocasionalmente a la palestra pública del papel impreso y venal.

\section{TEXTOS}

Se editan ambos pliegos con una anotación básica que pretende aclarar solo las dificultades contextuales, léxicas y de sentido más relevantes. Se modernizan grafías, acentuación y puntuación. Así, se adoptan las formas actuales para la alternancia de $s / s s, c / z / c ̧, x / j / g, v / b$; para el uso o no de $h$, y para las variantes gráficas $i / j / y, u / v, c / q,-m b-/-n v-, f / p h, l / l l$ (sin valor palatal). Se conservan grupos consonánticos cultos si perduran hoy, pero no en caso contrario (assumpto>asunto), y no se restituyen consonantes suprimidas (vitoria); siguiendo la grafía actual, $-s t-$ se transcribe a veces como $-x t-$. Se opta por hielo en vez de yelo; pero se respetan oscilaciones vocálicas y consonánticas de la época. Se realizan las contracciones al y del, y se deshacen las del tipo desta, della, etc. En nombres propios se sigue un criterio algo más conservador, como con Josef (Joseph), o con Vivarrambla (frente al posible Bibarrambla), que, pese a desfigurar su etimología árabe —y quizás por ello-, fue común en la época; en cambio, se edita Jesucristo (Iesu Christo). El uso de mayúsculas y minúsculas se atiene al actual, aunque con flexibilidad en términos metáforicos de referente religioso. Las abreviaturas se resuelven sin indicación; las otras adiciones de la editora aparecen entre corchetes.

Adorno de la Plaza de Vivarrambla en el día que la muy nombrada y gran ciudad de Granada celebra su fiesta al Santísimo Sacramento, con la explicación de pinturas, alegorías y versos. Por el Maestro Salvador de Morales, Presbitero, vecino de la misma ciudad.

Palestra hermosa, en quien con mil primores compiten los pinceles y las plumas, es hoy aquesta plaza: los pinceles, copiando en nueve lienzos de admirable grandeza otras tantas historias de las sagradas letras, de quien se deducen alegorías que se ajusten al divino y soberano Sacramento del Altar; las plumas, explicando con elegantes versos las pinturas y aplicando las alegorías al misterio. Hermosa competencia, bastante a realzar los aseos vistosos que a toda la plaza la ciñen y rodean, como son los altares suntuosos, bordados, frisos, tarjas vistosas con ángeles que las sustentan y finalmente los festones guarnecidos de flores y brutesco, en quien se ven grabados tan heroicos y conceptuosos versos (y siendo todo admiración del arte y suspensión de los sentidos). Dejo de explicar por extenso estos y otros lucidos aparatos, para 
cuya ejecución era forzoso valerme no de uno en que me limito, sino de muchos y muy dilatados pliegos.

En forma de academia dispuse las poesías, repartiendo nueve asuntos a otros tantos ingenios, hijos de esta ciudad, y muy favorecidos de las Musas, como en tantos actos lo publican sus acreditados lucimientos. Mas suspéndase mi voz en sus aplausos, cuando sus sonetos serán el mejor desempeño de mis ignorancias, y sus admirables primores, el mayor aplauso de sus aciertos. Para que todos sean más notorios, ya mi pluma a que ejerciten las suyas los invoca con este mal limado soneto.

\section{SONETO}

Suaves cisnes, que el cristal sonoro

a los acentos vuestros lo desata

el Genil, para ser violín de plata,

el Dauro, lira con los trastes de oro,

cantad, cantad, pues ya con gran decoro, mientras vuestra armonía se dilata (del oído lisonja la más grata),

suspenso aguarda el castalio coro.

Del sacro texto os propongo asuntos (ameno campo de divinas flores), que diestra mano copia sus trasuntos

en lienzos que realzan los colores.

Cantad, pues celebráis con dulces puntos

a un Sol que oculta en nubes resplandores.

\section{ASUNTOS}

Hizo principio a tanto adorno el primer lienzo, en quien se ve copiada la historia que refiere el cap. 43 del Génesis, cuando Josef, siendo virrey de Egipto, haciendo un espléndido convite a sus hermanos, juntamente sentó con ellos a la mesa algunos de los más nobles y principales egipcios. Pidiose se refiriese la historia y se alegorizase al misterio, y cumpliendo con ambos asuntos, escribió el soneto siguiente don Francisco de Trillo y Figueroa.

\section{SONETO}

Josef, en el convite celebrado a sus deudos y extraños juntamente, es sombra, más que el Sol resplandeciente, de Cristo en el altar sacramentado: uno y otro vendido fue y comprado de quien obedecido y obediente ${ }^{21}$,

${ }^{21}$ El final del período en el cuarteto aconseja suponer un zeúgma: «comprado de quien [fue] obedecido y obediente», en referencia a la venta de José por parte de sus hermanos y de Cristo por Judas. 
la cadena honorando la alta frente, que ya el desprecio había eslabonado.

Si en sombra extiende el Sol del Sacramento tanto los rayos de sus luces claras que a su esplendor es rey el desvalido,

hoy, que no hay sombra opuesta a su ardimiento, será deidad en sus piadosas aras quien ardiere en sus aras condolido.

El segundo lienzo retrata el suceso que refiere el cap. 15 del Éxodo. Sedientos tres días caminaban los israelitas por el desierto, hallaron un río que por su grande amargura le llamaron Mará. Aflígese el pueblo y dales Dios favor, mostrándole a Moisés un madero que, arrojándolo en las aguas, quedaron dulces y suaves, con que bebiendo de ellas satisfacieron todos su sed. La explicación y alegoría incluyó don Laureano Antonio de Morales en el soneto que se sigue.

\section{SONETO}

En el desierto el pueblo permanece con sed tres días, y a su sed extraña en tres días estéril le acompaña el agua solo que en su llanto crece.

Amargo un río al capitán se ofrece, en quien un leño misterioso baña, y dulce el agua ya por la campaña al contacto imperioso le obedece.

El pueblo bebe, a quien Moisés pregona, ya su sed en un leño redimida, que su bebida sazonó sagrado:

imagen de otro leño ${ }^{22}$ que sazona, en mejor redención, una comida en que hoy Dios se nos da sacramentado.

En el tercer lienzo se ve copiado lo que refiere el cap. 10 de Josué. Este valeroso capitán, siguiendo al enemigo en los alcances, al ver que el sol caminaba hacia el ocaso y que su ausencia le impediría su vitoria, vuelto a él le dice que se pare. Parose el sol en la mitad del cielo. Viose, pues, tan gran portento, porque quiso Dios obedecer la voz de un hombre, la voz de Josué, como lo advierte el sagrado texto: «Obediente Domino uoci hominis, et pugnante pro Israel». A este asunto, debajo de los preceptos dichos de explicación y alegoría, escribió don Nicolás de Cervantes y Ervías el soneto siguiente.

\section{SONETO}

«iSuspende el curso en tu esplendor luciente!

—al sol le dice Josué, imperioso-

\footnotetext{
${ }^{22}$ El leño de la cruz (véase también, en el pliego de villancicos, planta).
} 
¡Detente, y no mi esfuerzo valeroso quieras obscurecer con tu occidente!»

A su voz se detuvo, y obediente su término dilata luminoso por no estrechar a un día presuroso las hazañas de un ánimo valiente.

Paró a su voz las luces obsequiosas en su esfera este sol, mas si, encendido, sombra es del Sacro Pan, ya no os asombre, pues con cinco palabras misteriosas ${ }^{23}$ de su esfera a otro más esclarecido hace siempre bajar la voz de un hombre.

A Gedeón, capitán del pueblo hebreo, manifiesta el cuarto lienzo, que saliendo a reconocer en el silencio de la noche el ejército del rey de Madián, oyó un sueño que un soldado refería a otro, de que un pan iba rodando hasta la tienda de su rey, a que respondió el otro soldado: «Este pan no es otra cosa sino la espada de Gedeón, que nos ha de vencer y derrotar», Iud. c. $7^{24}$. Escribió sobre este asunto don Félix de Sandoval, cumpliendo con lo propuesto, por el tenor siguiente.

\section{SONETO}

De la quietud nocturna los sentidos despierta el alma a bélicos cuidados, al mirar Madián que sus soldados de un pan (sagrado Marte) son vencidos.

Intérpretes, los sustos advertidos, de Gedeón publican coronados los alfanjes $y$, en triunfos figurados ${ }^{25}$, de Madián los cuellos divididos.

¡Oh tú, del pan original glorioso a quien del trigo militares hojas cuchillas son de infieles adversarios!, tus vitorias alterna, misterioso, cándidas ya en el pan, ya en sangre rojas, vida de fieles, muerte de contrarios.

El quinto lienzo retrata a Manue, padre de Sansón, y a su mujer, ofreciendo agradecido sacrificio a Dios por la sucesión del hijo tan valeroso que habían de tener, y el mismo ángel que bajó a anunciarles lo que tanto deseaban lo

\footnotetext{
${ }^{23}$ Alusión a las palabras del canon pronunciadas por el sacerdote: «Hoc est enim corpus meum».

${ }^{24}$ Se trata del libro de los Jueces (Iudices).

${ }^{25}$ Recuérdese el concepto de figura ('representación o semejanza que se halla en alguna cosa, respecto de otra', Auts.), operativo en todas estas escenas bíblicas y en este poema concretado en el pan que protagoniza el sueño del soldado.
} 
vieron subir al cielo en las mismas llamas del sacrificio, Exod. c. 1326. Esta historia, y su alegoría en el soneto que se sigue, escribió don Juan Rubio de la Fuente.

\section{SONETO}

Esta oblación que en ara misteriosa los resplandores de sus luces gira es una sombra en cuya luz se mira la sucesión de Manue y su esposa.

Al que anunció promesa tan dichosa el incendio le erige excelsa pira, mas sin violencia, porque ve que aspira al centro de su esfera luminosa.

Cristo desde [el] altar se ofrece al cielo, sube el que baja a estar sacramentado para ser de la gracia inmenso abismo ${ }^{27}$, que al darse Dios por víctima en el suelo, el retorno mayor es limitado: sólo Dios puede serlo de sí mismo ${ }^{28}$.

La valentía del pincel nos retrata en el sexto lienzo al príncipe Jonatás alcanzando con la extremidad de la vara la dulzura de la miel que le ofrecía un panal a quien guardaba el tronco de un árbol, con cuya suavidad cobró el aliento que había perdido en el cansancio de una batalla que había tenido con los filisteos, de quien llegaba triunfante y vitorioso ${ }^{29}$. Con las condiciones dichas, sigue los asuntos don Sebastián Antonio de Gadea en la forma que se sigue.

\section{SONETO}

De su ardimiento Jonatás vencido, bien que de su contrario vitorioso, llega donde un panal (fruto ingenioso que adoptó un rudo tronco) ve advertido.

Imprime en él la vara ${ }^{30}$, en que exprimido el rubio néctar gusta fervoroso, que su espíritu alienta misterioso en el dulce recreo de un sentido.

\footnotetext{
${ }^{26}$ Hay errata en la referencia bíblica: el episodio se halla, en realidad, en Jueces, 13.

${ }^{27}$ Abismo: 'Metafóricamente se toma por todo aquello que por su profundidad, grandeza o multitud no es fácil a la comprehensión humana' (Auts.).

${ }^{28}$ Retorno: 'paga, satisfacción o recompensa del beneficio recibido' (Auts.). Remite a la consideración de la muerte de Jesús como precio de un rescate (Mc 10,45); sobre este concepto se elaboró la teoría de la satisfacción o del sacrificio expiatorio de Cristo: «la ofensa infinita de Dios por el pecado exigía también una expiación infinita, que sólo podía ser realizada por la muerte del Hijo de Dios hecho hombre» (Fries, 1979: II, 491, entrada «Redención», a cargo de W. Dettloff).

${ }^{29}$ El episodio se halla en I Sam 14, 27.

${ }^{30}$ Imprimir: 'aplicar, apoyar oprimiendo', por latinismo.
} 
¿Qué importa que de honor la heroica frente corones, oh mortal, si, al peso humano rendido, el brazo hace enfermar la gloria?

La Eucaristía gusta reverente, panal en cuyo aliento soberano hallarás sin achaques la victoria.

Llega David con sus soldados necesitados de sustento a la ciudad de Nobé (representa el séptimo lienzo) y Achimelec, al darle los panes sagrados, no teniendo otros, hace examen riguroso de la pureza de sus conciencias para dárselos, I Reg. cap. 2. Guardando las leyes dichas, explicó este asunto don Fernando Carvajal y Pacheco.

\section{SONETO}

Huye la saña de Saúl ardiente David, y de Nobé las torres mira, en cuyo sitio Achimelech se admira de ver la majestad tan indecente.

Ruégale al sacerdote dé a su gente sustento, que advertido le retira hasta que el casto examen a que aspira del sagrado manjar le hizo decente.

Propio retrato de este pan divino, en quien obró, el poder y amor iguales, su desempeño la mayor fineza,

hoy se ofrece, bocado peregrino: llegad con perfección, llegad mortales, pues la vida os importa la pureza ${ }^{31}$.

La hermosa Abigail desenoja a David con un presente, en que le dio abundancia de pan y de vino, y aplacado David, templa los castigos que determinaba ejecutar en el avariento Nabal, y a la piadosa Abigail le dice: «Bendita tú que has suspendido mis castigos para que use de piedades», I Reg. c. 25. Guardando la historia, siguió la alegoría don Juan de Trillo y Figueroa.

\section{SONETO}

No bien la dura frente al justo acero pudo temer Nabal ensangrentada, cuando suspende Abigail postrada, voz de león con sombras de cordero.

Pan y vino conduce al rey severo, cuya fe, con misterios ilustrada, «iBendita - dice—, oh tú, que de mi espada hallas piedad en el rigor primero!»

Ofrece al Padre nuestra Iglesia Santa el cuerpo y sangre de Jesús divino

\footnotetext{
31 'En la pureza os va la vida'.
} 


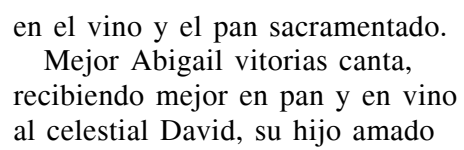

A Saba, reina del Austro, retrata muy al vivo el último lienzo, que admirada de la sabiduría del rey Salomón y de lo abundante de su mesa y demás grandezas, dijo: «Dichosos tus siervos, que merecen gozar de tu presencia», 3 Reg. c. 10. Cumplió con las condiciones propuestas en este soneto don Gaspar Afán de Ribera, caballero del Orden de Santiago.

\section{SONETO}

Saba, reina del Austro peregrina, halla en Jerusalén su rey prudente, admira su grandeza y, elocuente, la voz levanta cuando el cuello inclina.

« $\mathrm{OOh}$, venturosos — dice- en Palestina

los que asisten tu mesa con fe ardiente, cuyo manjar es sombra reverente de una luz, que será oblación divina!»

$\mathrm{Si}$ regia voz aclama el ejercicio de aquellos siervos, ¡cuánto más se abona quien sirve al ara y logra el beneficio!

Hoy mejor Salomón desaprisiona al hombre, que al gozar su sacrificio pasa de la cadena a la corona.

Deme la elocuencia voces para repetir elogios debidos. Mas, puesto que las mías, por toscas y mal limadas, no pueden explicar mis afectos agradecidos, manifieste este soneto, aunque con rudo estilo, mis reconocidos deseos.

\section{SONETO}

Cuando cantado habéis tan dulcemente que admirada a Calíope habéis dejado, y cuando al sacro metro habéis juntado lo agudo con lo grave y elocuente,

no la rama de Dafne es suficiente, no, a vuestras sienes premio aventajado, lauro, sí, es propio, y de justicia dado, que el mismo Apolo os ciña el de su frente.

Bellos rubíes sois de esta Granada, en lucir imitáis al diamante, vuestra fatiga está muy bien premiada.

No vuestro premio se verá inconstante, si cultos dais a una beldad sagrada, Dios escondido y manifiesto amante.

Habiendo el doctor don Sancho de Guzmán Portocarrero, caballero del hábito de San Juan y capellán de honor de Su Majestad en su Real Capilla, escrito este soneto por su devoción sobre el cuarto asunto, me pareció ponerlo aquí. 


\section{SONETO}

Las luces bellas del augusto día borró la noche, y Gedeón valiente oye a un soldado el vaticinio ardiente de un pan que las campañas destruía. Sus ruinas llora la corona impía del madianita rey (¡fuerte accidente!): el sustento, que espada ya es luciente, sea estrago fatal a su osadía.

Más vos, Señor, que en pan a los mortales al daros por manjar ya nos advierte vestirnos de temor a tal comida. ¡Oh, cómo atiendo efectos desiguales!, que si dais vida en vuestra propia muerte, nos damos muerte en nuestra propia vida.

Y tú, ¡oh famosa ciudad de Granada!, apuesta con la fortuna tus felicidades, que siempre saldrás vencedora, puesto que la devoción con que sirves al Señor más soberano, a pesar del olvido, eterniza tu memoria.

En Granada, en la Imprenta Real, por Francisco Sánchez, en frente del Hospital del Corpus Christi. Año de 1661.

Omnia sub correctione Sanctae Romanae Ecclesiae.

\section{II}

Villancicos que se han de cantar en la Santa Iglesia Apostólica y Metropolitana de Granada, en los Maitines del Nacimiento de N. S. Jesucristo, este año de mil y seiscientos y sesenta y cuatro. Dedicados al señor D. Juan Benítez Montero, Colegial en el Mayor de Cuenca de Salamanca y Catedrático de su Universidad, Canónigo Magistral de la Santa Iglesia de Badajoz, Vicario General del Ejército de Extremadura, electo Obispo de Gaeta, Calificador del Supremo Consejo de la Santa Inquisición y Deán de esta Santa Iglesia Metropolitana de Granada.

Aunque los villancicos de la Navidad son preciso cuidado de mi obligación, no cumpliera yo con el empeño de prevenirlos si no acertara con la elección de dedicarlos. Y así, consagro a V. S. este desvelo, que, aunque pequeño, puede presumir, por las dos composiciones, de dos veces numeroso y de muchas feliz con tan grande patrocinio, logrando yo que en las manos de V.S. no solo hallen los aciertos de esta obra estimación, sino sus errores desvanecimiento. Guarde Dios la vida de V. S. muchos años como deseo, etc.

B. L. M. D. V. S. su Capellán, y M. S ${ }^{32}$.

Luis Garay

32 'Besa las manos de Vuestra Señoría su capellán, y mayor servidor'. 


\section{CONVOCATORIA}

A la Academia, ingenios soberanos, venid, donde cede el laurel a la oliva, porque es paz la lid.

Venid a coronaros, donde veréis lucir un Apolo divino, que os premie con solo el venir.

Y si vuestro certamen hoy acierta a aplaudir, de la Tierra la paz en el Cielo la gloria ha de oír.

\section{Estribillo}

Venid, ingenios, venid, y pues baja el Apolo más alto, venid como rayos, para que el mundo feliz celebre, lleno de gozos, el verle entre los embozos de un encarnado matiz ${ }^{33}$. $\mathrm{Ea}$, venid, ingenios, ea, venid a escribir volando, que plumas ingeniosas vuelan en las manos.

Venid a la Academia, que os aguarda una Noche Buena; a Belén, ingenios, a Belén, sin riesgo ${ }^{34}$ las plumas en su luz encended: venid a celebrar a un Sol que, para nacer, se nos pone en un portal.

Vaya de fiesta, vaya.

Uno. ¿Harán armonía las veras y chanzas? Vaya.

Otro. ¿Lo grave y festivo harán consonancia? Vaya.

Otro. ¿Darase vejamen que pica y no abrasa? Vaya.

Pues haya vejamen, y nadie se corra, que todos llevarán.

${ }^{33}$ Por su color sonrosado, y también por haberse «hecho carne», en dilogía análoga a la de otros villancicos del pliego.

${ }^{34}$ La sencillez del sintagma puede esconder una alusión a Ícaro, paradigma de osadía con el que a veces se identificaban los poetas. Aquí estos pueden componer inspirándose en Cristo («encender sus plumas en su luz») sin temer los riesgos de la escritura, evocados en otros pasajes del poema: la pugna entre ingenios, la censura o el vejamen hiriente, y no simplemente festivo, o aun la mera - y perecedera - gloria mundana. 
Uno. ¿Qué?

¿Qué? Tengan, oigan

vejamen que es gracia

y aplauso que es gloria;

pues hay gloria y gracia,

vaya de fiesta, vaya.

\section{Coplas}

Al más soberano Apolo, que ilustrando a Belén hoy, viene a un tiempo a media noche, y viene al salir del Sol,

la devoción le compone una Academia, a quien dio su nueva luz nuevo asunto, nuevo influjo y nuevo ardor;

cuyo sagrado certamen publica la paz mejor que la lid, pues la Poesía es toda composición ${ }^{35}$.

El primero asunto escriban haciendo obrero al Señor las virtudes, pues es de ellas propia la edificación.

En comisión regidores pinte otro asunto, que a Dios fieles sirvan sin salario, pero no sin sumisión ${ }^{36}$.

De Noche y Día, otro ingenio retrate la oposición, siendo sus luces y sombras el estudio del pintor.

En el cuarto asunto aplauda la flor que hoy nace otra voz con ecos, porque fragrantes resuenen de flor en flor.

Otro ingenio una gaceta escribirá, y tengan hoy sus nuevas autoridad, pero no suposición ${ }^{37}$.

El último asunto sea de una pandorga el rumor, que en su son alegre suenen más instrumentos que son.

\footnotetext{
${ }^{35}$ Aparte del sentido de 'texto', recuérdese que componer «vale asimismo terciar y contribuir para que los que están discordes en alguna cosa se conformen y vengan en ella» (Auts.)

${ }^{36}$ Se juega con el calambur «su-misión».

${ }^{37}$ La cuarteta se cierra con una paradoja, pues suposición significa 'autoridad, lustre', pero también 'acción de suponer' e incluso 'impostura o falsedad' (Auts.), conceptos de antitética aplicación a un género noticiero como la gaceta.
} 
Dará fin a la Academia

un vejamen, que veloz

no penetre, sino pase

sin que se sienta su arpón.

\section{ASUNTO PRIMERO}

\section{Estribillo}

A la Obra de la Iglesia

llegad, llegad apriesa, venid a ver sin zozobras

el edificio mejor,

que hoy le empieza un Maestro mayor,

que sólo se paga de buenas obras ${ }^{38}$.

Venid apriesa,

que parte, que baja, que viene, que llega:

venid con vigilancia,

que el Maestro pone el trabajo,

porque vosotros tengáis la ganancia.

¡Oh, cómo espanta

que a hacer venga una obra de ley,

siendo de gracia $^{39}$ !

Ande la obra, jornaleros, ande.

$\mathrm{Y}$ pues al mar del mundo quiere entregarse,

fabríquense las naves ${ }^{40}$,

ande la grúa,

suba la piedra, ande, suba,

porque hoy es la rueda de nuestra fortuna.

Suba la Iglesia en los arcos, suba,

para ver la gloria de Dios en las alturas,

suba en los arcos, porque veamos

la paz del hombre también en los $\operatorname{arcos}^{41}$.

\section{Coplas}

Albricias, hombres, albricias, pues cumpliendo su promesa,

se vino el Maestro abajo

para levantar la Iglesia.

${ }^{38}$ Se paga de: 'Se contenta de'; además, permite evocar el sentido de 'es pagado con', a modo de salario, en un contexto laboral que se explicita versos más abajo en los términos trabajo / ganancia.

${ }^{39}$ Para obra de ley, adviértase que ley es la 'conformidad que los géneros o mercaderías tienen con las leyes y establecimientos de las fábricas' (Auts.). Se juega con la antítesis entre la era de la ley de Moisés (o ley antigua), y la de la ley de gracia ('la que Cristo Señor Nuestro estableció y nos dejó en su Evangelio', Auts.).

${ }^{40}$ Dilogía entre las naves de esa iglesia en obra y las que surcan el «mar del mundo» —recuérdese la tradicional alegoría de la Nave de la Iglesia-, aunque luego no se prolonga la evocación marítima.

${ }^{41} \mathrm{La}$ asociación entre paz y arcos remite ahora al arco iris, símbolo de la alianza entre Dios y sus criaturas tras el diluvio (Gn 9, 12-17). 
Ya sacó el primer cimiento, mas tan profundo lo encuentra, que anduvo haciendo misterios ${ }^{42}$, hasta dar en Virgen Tierra.

El material y el Maestro es a un tiempo, pues ostenta en lo Humano y lo Divino la más bien unida mezcla.

Por su amorosa ternura y nuestra ingrata dureza, si le dan sus ojos agua, nuestros corazones piedra.

La planta que da a la obra, es para enmendar aquella planta que causó la ruina de la fábrica primera ${ }^{43}$.

La porción de tierra humana dará corriente moneda para costear la obra del tesoro de sus venas ${ }^{44}$.

Y porque en su Iglesia estéis, que será un Cielo su Iglesia, al fin os dará el Maestro la entrada por cinco puertas ${ }^{45}$.

Esta noche a un portal pobre llegó, que como se emplea en reparar las ruinas, busca el hospedaje en ellas. A la Obra, etc.

\section{ASUNTO SEGUNDO}

Castellano Yo, el Regidor Payo Blázquez, fidalgo que só, maguer ca non tiengo que yantar, rico ome de gran prez.

Morisco. Yo, el Regedor Bedro Meca, que estar moresco de ben, de aquelios que con bonetes server en Orán al Rey.

\footnotetext{
${ }^{42}$ Aparte de aludir al misterio de la Encarnación, se juega con hacer misterios: 'no querer manifestar ni descubrir alguna cosa a otro, ponderando su gravedad y el peligro que corre el que se publique' (Auts.).

${ }^{43}$ La dilogía de planta continúa la serie de alusiones arquitectónicas, remitiendo a su vez a dos «árboles» bíblicos de contrarios efectos: el árbol de la Ciencia del Bien y el Mal, que con la tentación de Adán y Eva causó la perdición del hombre, y el «árbol» de la cruz de Cristo, que propició su salvación.

${ }^{44}$ Vena: 'el ramo de los metales, que se crían en lo interior del cuerpo de la tierra' (Auts.); y también referencia a la sangre de Cristo.

${ }^{45}$ Las cinco llagas de Cristo.
} 
Castellano. De esta Pascua comisario a nueso Dios con pracer mi pecho asaz acucioso un[a] fiesta le previén.

Morisco. Del Jonior Alá chequelio ser comesareo tambén, e aunque renegue el Gran Torco, hacerle un zambra querer.

\section{Estribillo}

Castellano. ¿Zambra, siendo regidor el mío lustror?

¿Non es mijor facerle una danza con humildanza?

Morisco. Más bono istará jacerle il zalá ${ }^{46}$.

Castellano. Non atañerá.

Morisco. Sé atoñará más sabroso que alcozcoz, que bara jacer il zalá, el moresco jacer el Croz.

Castellano. Non fables, roín alimaña, donde fabla un fidalgo de la Montaña.

Morisco. ¡Ah, jonior jedalgo, tente!, que tambén il moresco estar gente.

Castellano. Calla, sandio, o farete en la testa un foraco.

Morisco. E yo con vetorias bor me gosto romber jecotorias ${ }^{47}$.

Castellano. Aguarda, soez, que te he de finar.

Morisco. Bues bener, que aqué estar.

Alcalde. Bueno está, Regidores, no haya más riña, y ténganse a la justicia, que aunque soy el Alcalde Chiquito, gracioso y bonico, para quietar el furor, he de ser el Alcalde Mayor; cese el ruido, tened, parad, y pues celebráis paz que ha nacido, la pendencia se quede en paz.

Castellano. Pues ya que el Infanzón hoy nos face ayuntar, de aquesta guisa finque nuestra brega en solaz.

Y fáganse una fiesta que non haya más.

\footnotetext{
${ }^{46}$ Zalá: 'La adoración o reverencia que hacen los moros a Dios y a Mahoma [...]' (Auts.).

${ }^{47}$ [Carta] ejecutoria era «la de la hidalguía, que tiene el que es hidalgo, por haber litigado y salido con ella» (Auts.).
} 
Morisco. Bues mandar il Chequelio

Cemetarra envainar

E nuestra mal belea

Quedar sin sana baz,

demos bremcepio al zambra

con un hai, hai, hai.

Castellano. Demos folganza a aqueste

Sol, que es fidalgo asaz, pues en un rayo y otri

se le otea el solar $^{48}$.

$Y$ fágase una fiesta, etc.

Morisco. De aqueste Jonior grande se ablanda la homildad, bues se hacer rey chequelio, e baja a estar Bajá.

Demos bremcepio, etc

\section{ASUNTO TERCERO}

Contra la noche mueve resplandeciente guerra el día, porque nace

Dios en ella.

Hoy se revela contra

la ambiciosa tiniebla, porque a su luz tal dicha no revela.

$\mathrm{Y}$ en su encuentro la noche teme fortuna adversa, con tener de su parte las estrellas.

Cobarde se previene, pues si vencida queda, vendrá a ser para el día Noche Buena.

\section{Estribillo}

Arma, arma, guerra, guerra, aquí de las luces, aquí de las tin[i]eblas,

Alístense los rayos, prevénganse las sombras, que este Oriente le toca a la noche, al día le toca. Que sí puede ser; que no; que sí, pues al sol las estrellas de noche le ven lucir. Que no puede, no, sino sólo en el día nacer el Sol.

Arma, arma, guerra, guerra, aquí de las luces, que la noche cierra.

Cierra, cierra, noche, porque el día rompe ${ }^{49}$.

\footnotetext{
${ }^{48}$ 'Se le ve el solar de donde procede', con la voz solar en su contexto genealógico, pero aquí también con relación pseudoetimológica con sol.

${ }^{49}$ Se combina la específica acepción bélica (cerrar: 'embestir, acometer un ejército a otro'; romper: 'desbaratar u deshacer un cuerpo de gente unida' o 'abrir espacio suficiente
} 
Vitoria, vitoria, que se van fugitivas las sombras.

Mas tened, no haya más,

que es impropia la guerra cuando todo es paz,

y venga a ser el día

de la noche hermosura, no tiranía,

porque triunfe la noche,

pues liberal le ofrece sus resplandores.

\section{Coplas}

Sombra y claridad se junten

a rendirse a un Dios conformes, que a unir enseña naciendo distantes oposiciones.

Celebren su Oriente, unidas

Tiniebla y Luz, Día y Noche, pues les da ejemplar, juntando

Cielo y Tierra, Dios y Hombre.

Pues nace el Sol, venga el día,

y lleguen sus resplandores

tan templados que las sombras

más se ilustren que se asombren ${ }^{50}$.

Tan presto tal bien avisen, que antes cuenta en los pastores

den a los ojos las luces

que a los oídos las voces.

$\mathrm{Y}$ en paga a la luz nocturna, de un astro el día no estorbe, que desde Oriente a este Oriente sirva a tres cetros de Norte.

Y mude el combate el día, oponiendo sus ardores a los asaltos del hielo, que hicieron temblar la noche.

\section{ASUNTO CUARTO}

Generoso hoy da el Diciembre Hoy da el Diciembre

a un Dios, que es Flor misteriosa, Flor misteriosa

y es Hombre que vio encarnadas que vio encarnadas

florecer sus bellas hojas sus bellas hojas.

Hoy da el Diciembre

Flor misteriosa

que vio encarnadas

sus bellas hojas

para pasar, en el sitio o paraje ocupado de gente unida'), con expresiones hechas habituales: cerrar la noche ('acabar de anochecer') o romper [el día] ('hablando del sol u de la luz, vale vencer con su claridad') (Auts.).

${ }^{50}$ Asombrar: 'Obscurecer, hacer sombra una cosa a otra' (Auts.). 
A un tiempo feliz le admira purpúreo la tierra toda, y alcanza lo que trasciende fragrante desde la Gloria

Feliz le admira la tierra toda lo que trasciende desde la Gloria.

Su esplendor hoy no madruga en Belén sin luz, pues goza con María a media noche la clara luz de la Aurora.

Hoy no madruga sin luz, pues goza a media noche luz de la Aurora.

El llorar con nuevo estilo al nacer se halla en su aljófar, pues vemos que un Alba enjuga rocío que una flor llora.

Con nuevo estilo se halla en su aljófar que un Alba enjuga, que una flor llora.

Solo ya cuando rodean de esta flor la luz que arroja, ardientes los hielos quieren llegar a ser mariposas.

Cuando rodean la luz que arroja, los hielos quieren ser mariposas.

¡Qué mucho dé flor tan bella al mundo la planta hermosa virginal, a quien Dios hizo liberal con su luz sombra.

Dé flor tan bella

Con nuevo estilo se halla en su aljófar que un Alba enjuga, que una flor llora.
Feliz le admira

la tierra toda

lo que trasciende desde la Gloria.
Hoy no madruga sin luz, pues goza a media noche luz de la Aurora.
Cuando rodean la luz que arroja, los hielos quieren ser mariposas. Dé flor tan bella
la planta hermosa
a quien Dios hizo
con su luz sombra. la planta hermosa a quien Dios hizo con su luz sombra.

\section{Estribillo}

Albricias, albricias, recebid parabienes, albricias, pues os da el Alba, venciendo los hielos, con esta flor el fruto más feliz de la esperanza.

Recebid parabienes, pues os da el Alba, con esta flor el fruto de la esperanza. 
Recebid parabienes, pues os da el Alba con esta flor el fruto de la esperanza.

\section{ASUNTO QUINTO}

Oigan, señores, oigan

una gaceta

que nos da, que nos da buenas nuevas.

¿Qué dice cierto?

Muchos prodigios,

pues nos dice que Dios ha nacido.

Pues diga, y oigamos.

Oíd muchas nuevas, y todas de un parto:

¡vaya de gaceta!

4

Si ella es en verso, será compuesta.

Oigan atentos, que esta epístola no es $A d$ Efesios $^{51}$.

\section{Coplas}

Dícese de la región de Judea por muy fijo que, causando admiración, parió una Virgen un hijo sin saber qué era varón.

También por cierto ha corrido, y lo han dicho más de dos, que en el Verbo que ha venido un sermón ${ }^{52}$ nos ha nacido, que es la palabra de Dios.

De un buey dice cierta carta que de abrigarle amorosa la respiración no aparta, siendo, por ser tan piadosa, cada nariz una marta ${ }^{53}$.

Y que una mula se halló, a quien el buey sobrepuja, porque con ninguno habló, mas al fin se disculpó con que era de la Cartuja ${ }^{54}$.

${ }^{51}$ En el impreso: «adefesios»; restituyo la grafía culta por la conexión literal con la epístola paulina, pero recuérdese el sentido de adefesios como 'despropósitos, palabras o proposiciones dichas fuera del intento' (Auts.).

${ }^{52}$ En autores cristianos como Tertuliano o Prudencio, sermo significaba también 'Verbo Divino'.

${ }^{53}$ La dilogía apunta a las apreciadas pieles de este animal y a la diligente y activa hermana de Lázaro.

${ }^{54}$ Remite a la prescripción de silencio en esta orden religiosa; dado el usual remate ingenioso de las coplas, debe de haber además alguna alusión de carácter local o popular que asociara las mulas con la Cartuja o sus alrededores. 
Dicen que ángeles venían, y aunque el cielo se desagua lloviendo, no se volvían, que entre la lluvia caían los ángeles como agua ${ }^{55}$.

$\mathrm{Y}$ que aqueste nacimiento a unos pastores (que es harto) dijo una luz en el viento, con que tuvieron del parto ellos el alumbramiento.

Del Niño la facultad las letras divinas son, mas que en la Universidad de este mundo su afición lo inclina a la Humanidad; que el enemigo triunfante perderá sus ocasiones, aunque es dragón militante, que hará huir solo este infante todo el tercio de dragones.

También es cosa notoria que un ángel bello, con faz de acólito, en tal vitoria a Dios le cantó la Gloria y al hombre le dio la paz.

También hay noticia fiel de una nueva singular, porque escriben que cruel Herodes, hecho un Cromuel ${ }^{56}$, quiere a su rey degollar;

y también que a tres varones una estrella conducía, mas sin duda que sus dones tocaban a los millones

\footnotetext{
${ }^{55}$ Juega con «agua de ángeles», en definición de Covarrubias (s. v. ángel), «de suavísimo olor».

${ }^{56}$ Oliver Cromwell (1599-1658), político y militar inglés, ejerció dictatorialmente el poder, tras propiciar el procesamiento y ajusticiamiento de Carlos I. Varios pliegos venían difundiendo su imagen negativa en España; por ejemplo: Relación de la famosa vitoria, que han tenido las armas del Duque de Saboya contra los herejes protestantes del valle de Ginebra, los cuales pidieron favor a Oliver Cromuel..., el cual le ofreció con grandísima arrogancia este año de 1655 (Sevilla: Juan Gómez de Blas); Relación de los nuevos decretos que el tiranísimo Cromuel ha hecho en Dublín en Irlanda para que se publiquen en las demás ciudades y lugares (Madrid: Domingo García Morrás, por su original en Granada: Imprenta Real, por Francisco Sánchez, 1657); Relación verdadera del testamento que hizo... Oliver Kromuel..., donde se declara y da cuenta de las disposiciones que dejó tocantes a la guerra y razones de Estado y liga con Francia contra España, y documentos que dio a su hijo el mayor..., y el entierro que mandó se le hiciese (Madrid: José Fernández de Buendía, 1658; Zaragoza: Juan de Ibar, 1658).
} 
puesto que entraron con guía ${ }^{57}$.

Estas son las más seguras nuevas que ha habido jamás y que andan en más alturas, con que logramos venturas, dichas y a Dios, que no hay más ${ }^{58}$.

\section{ASUNTO SEXTO}

\section{El mayoral Gil Carrasco} alegrar con el festejo de una pandorga pretende la noche del Nacimiento.

Juntó al punto sus zagales $\mathrm{y}$ a todos los fue vistiendo con una pandorga antigua que heredó de sus abuelos.

$\mathrm{Y}$ al moverse toda junta, se le caían de viejos sus trastos, pues al tocarles se andaban como cencerros.

Mas supliolo el escribano de su aldea, porque, ha tiempo, les dio de sus protocolos un legajo de instrumentos ${ }^{59}$.

Por el viento caminaban tocando, pero su estruendo $\tan$ pesado fue que nunca lo pudo llevar el viento.

Al portal después llegaron, y como al Niño Dios vieron, que era su fin, a alabarle comenzaron con Laus Deo.

\section{Estribillo}

Ande, zagales, el regocijo, con calor aunque hace frío, ande la fiesta sin parar, andar, andar, andar,

que aunque es destemplado el tiempo,

${ }^{57}$ Parecen combinarse dos dilogías: guía, en alusión a la estrella que llevó a los Reyes Magos al portal, y como 'despacho que lleva el que transporta algunos géneros, para que no se los descaminen'; millones, por el valor de los dones ofrecidos al Niño, pero también el impuesto conocido como servicio de millones.

${ }^{58}$ En cuanto a puntuación y edición, se prima aquí el sentido «serio» de la frase: con la buena nueva el hombre consigue no solo venturas y dichas, sino también a Dios, lo máximo que se puede lograr. Sin embargo, se juega también con un repentino cierre chusco de la relación: «con que logramos venturas, / dichas... y adiós, que no hay más».

${ }^{59}$ Instrumento: 'Escritura u otro papel que sirve para justificar alguna cosa o certificarla' (Auts.). 
a fe que los instrumentos no se lleguen a destemplar, andar, andar.

Suene la flauta y el rabel, la guitarra y el cascabel, toque Pascual el atabal, haciendo $\tan , \tan , \tan$, taran, $\tan$, y el esquilón, dilón, dilón, y el espadín, din, din, din, la ginebra ${ }^{60}$ y su run run, la zambomba con su bum, bum, las sonajas, chas, chas, chas, y el pandero, ta, ta, pa, ta, tan. Y todos juntos al compás, andar, andar, andar, que aunque es destemplado el tiempo, a fe que los instrumentos no se lleguen a destemplar.

\section{Coplas}

Celebremos con aliño a un zagal como un armiño, que siendo hombre se hace Niño, y que es punta su cariño, que le ha llegado a encarnar ${ }^{61}$.

Andar, andar, andar, que aunque es destemplado el tiempo, a fe que los instrumentos no se lleguen a destemplar.

Hagamos fiesta a María, pues le dio a nuestra alegría a media noche un buen día, con que la nación judía no tiene ya que esperar. Andar, etc.

Celebre la fiesta unida a Josef, que aunque en su vida no hizo a otra región partida, vio en su vara La Florida ${ }^{62}$ $\mathrm{y}$ en su mano vio El Casar ${ }^{63}$. Andar, etc.

\footnotetext{
${ }^{60}$ Ginebra: 'Instrumento grosero inventado solo para hacer ruido' (Auts.).

${ }^{61}$ «Encarnar la saeta, es asirse a la carne y hacer llaga» (Cov.); además evoca encarnarse, 'hacerse carne'.

${ }^{62}$ Para el juego con el topónimo americano, piénsese en la iconografía de San José con una vara florecida.

${ }^{63}$ El concepto estaba ya en Lucas Gracián Dantisco: «Como un cavallero que trayéndole loco a su tierra, preguntó al passar por una aldea: —¿Qué lugar es éste? -Y como dixessen que se llamava El Casar, respondió en este mote: - Quien passa por el casar, por todo puede passar—》 (1968: 150).
} 


\section{VEJAMEN}

Vaya de Villancico, que es el Vejamen que la Academia cierra, y a todos abre.

Nadie tema sus puntas, que a los poetas no hará sangre, aunque a todos pique en la vena.

Con mis chanzas dolores sientan, pues cuando al Nacimiento escriben andan de parto.

Pues dan fin los nocturnos ${ }^{64}$, lleven vejamen, y esta vez no a maitines se sigan laudes ${ }^{65}$.

\section{Estribillo}

Va de vejamen, atiendan y oigan, y nadie se corra, ni mis burlas de veras se tomen, pues puntas al aire más vuelan que corren ${ }^{66}$. No, no, no las teman, que aunque sean agudas, nada penetran. Del vejamen la carga comience, $\mathrm{y}$ antes que lleven el premio, que lleven, lleven la carga, que yo solo tiro a aquel que dispara ${ }^{67}$.

\section{Coplas}

Niño, la primer saeta os prevengo, que por lo desnudo os tengo por poeta; hoy os descubro una treta conocida, pues viniendo a darnos vida,

${ }^{64}$ Nocturno: 'una de las tres partes en que se dividen los Maitines, que consta de cierto número de salmos y tres lecciones' (Auts.).

${ }^{65}$ Laudes: 'Una de las partes del oficio divino, que se dice después de Maitines, y con ellos se compone la primera hora del rezo. Llámase así porque los más de los Salmos de que se compone son laudatorios' (Auts.).

${ }^{66}$ Puntas parece referirse a los encajes «de hilo, seda u otra materia, que por el un lado van formando unas porciones en círculo» (Auts.), probablemente en el cuello; evocando la correlación intensificadora correr-volar, esas puntas ondean al aire (vuelan), pero no corren. A la vez, para cerrar la idea de un vejamen dicho «de burlas», y no «de veras», debe recordarse otro sentido de correr ('avergonzar', 'maltratar').

${ }^{67}$ Aparte de la acepción más habitual de disparar, hay que considerar también la de 'decir o hacer cosas fuera de propósito y razón. Puede ser síncopa de disparatar' (Auts.). 


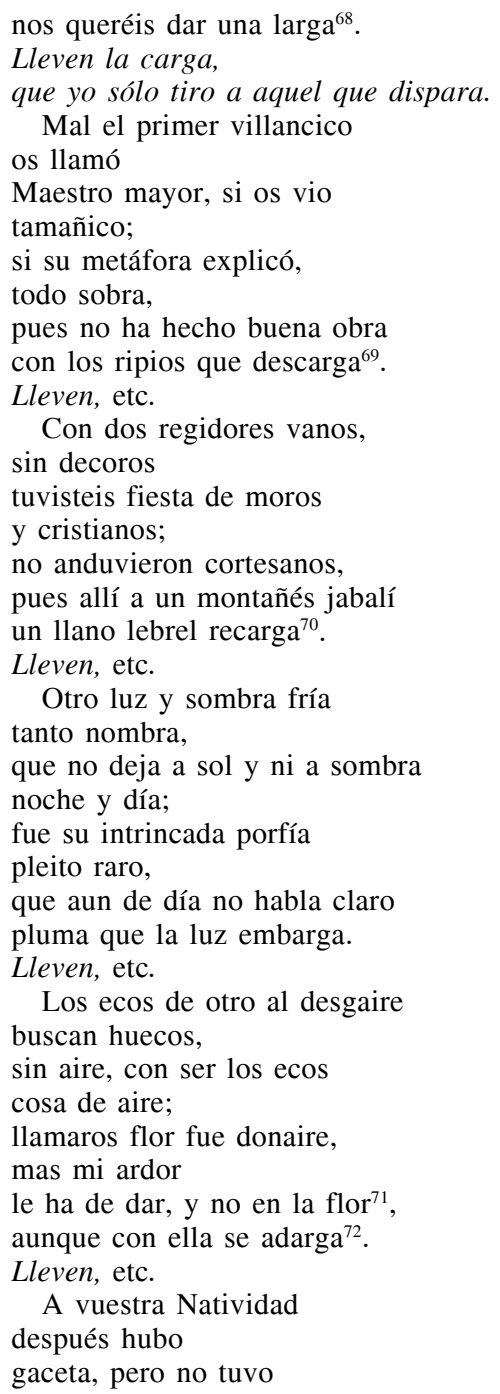

68 'Dilación, tardanza y entretenimiento de tiempo' (Auts.), pero se juega con el sentido usual y la elipsis: «vida larga».

${ }^{69}$ Ripio: 'Palabra u palabras que se ponen precisamente para llenar el verso y están de más en la sentencia' y 'fragmentos que quedan de los materiales desechados o quebrados' (Auts.).

${ }^{70}$ Recargar: 'Hacer nuevo cargo o reconvención' (Auts.).

${ }^{71}$ Dar en la flor: 'Frase vulgar con que se da a entender haber alguno degenerado en vilezas' (Auts.).

72 'Repararse o cubrirse con la adarga', pero también 'metafóricamente se dice del que se previene contra los agravios, injurias de sus contrarios, o contra las calamidades que le puede traer el tiempo' (Auts.). 


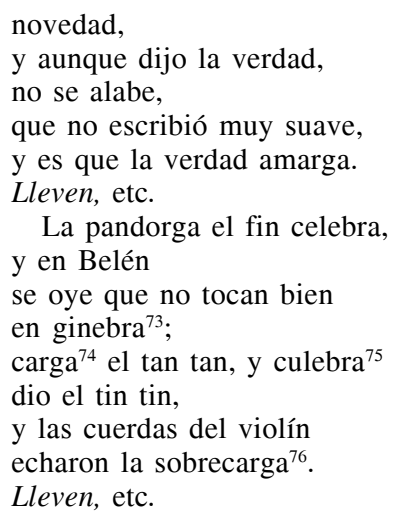

CON LICENCIA. Impresos en Granada, en la Imprenta Real de Baltasar de Bolíbar, en la calle de Abenámar.

\section{BIBLIOGRAFÍA CITADA}

Álvarez, Francisco J.; Ignacio García Aguilar e Inmaculada Osuna (2008). «SeventeenthCentury Academies in the City of Granada: A Comparatist Approach», en Arjan van Dixhoorn y Susie Speakman Sutch (eds.). The Reach of the Republic of Letters. Literary and Learned Societies in Late Medieval and Early Modern Europe. Leiden / Boston: Brill, vol. II, pp. 309-336.

Bègue, Alain (2007). Las academias literarias en la segunda mitad del siglo XVII. Catálogo descriptivo de los impresos de la Biblioteca Nacional de España. Madrid: Biblioteca Nacional.

Cara, Giovanni (2001). Il»vejamen» in Spagna. Juicio y regocijo letterario nella prima metà del XVII secolo. Roma: Bulzoni.

Carrasco Urgoiti, Soledad (1965). «Notas sobre el vejamen de academia en la segunda mitad del siglo XVII». Revista Hispánica Moderna. XXXI, pp. 97-111.

Cervantes Ervías, Nicolás de (1662). Descripción de las fiestas que al primero y purísimo instante de la Concepción de Nuestra Señora consagró el Real Convento de San Francisco de Granada. Granada: Baltasar de Bolíbar.

Cruz Casado, Antonio (2004). Villancicos barrocos del sur de Córdoba (siglos XVII-XVIII). Lucena: Ayuntamiento de Lucena.

${ }^{73}$ La precisión «en Belén» parece buscar la paradoja con la dilogía entre el nombre del instrumento y el topónimo suizo.

${ }^{74}$ Cargar: 'En términos de guerra es dar sobre los enemigos acometiéndolos y vigor' (Auts.); aunque quizás tenga un sentido menos específicamente bélico y más afín a términos siguientes (dar culebra, sobrecarga), próximo al de la expresión cargar sobre uno: 'Metafóricamente. Instarle, importunarle, echarse sobre él, y en cierta manera precisarle a que condescienda y haga lo que se le pide' (Auts.).

${ }^{75}$ Dar culebra: 'Dar algún chasco pesado, que suele ser con golpes' (Auts.).

${ }^{76}$ Sobrecarga: 'Metafóricamente [...] la cosa molesta, que sobreviene y se añade al sentimiento, pena o pasión del ánimo' (Auts.). 
Fernández Solana, Diego (1647). Fiestas que la famosa y leal ciudad de Granada dedica y ofrece al Santísimo Sacramento este año de 1647. Granada: Francisco Sánchez y Baltasar de Bolíbar.

Fries, Heinrich, dir. (1979). Conceptos fundamentales de la Teología. Madrid: Ediciones Cristiandad.

García-Plaza, Manuel (2002). Literatura popular impresa, 2. Pliegos de villancicos del siglo XVII (Noticias de una pequeña biblioteca. VI). Iglesias, Alejandro Luis (pról. y transcripción musical). Salamanca: [SEMYR].

Garrido Atienza, Miguel (1990). Antiguallas granadinas. Las fiestas del Corpus [1889]. José Antonio González Alcantud (ed. facs.). Granada: Universidad / Ayuntamiento.

Gracián, Baltasar (2001). El Comulgatorio, en Obras completas, Aurora Egido (intr.); Luis Sánchez Laílla (ed.). Madrid: Espasa Calpe.

Gracián Dantisco, Lucas (1968). Galateo Español, Margherita Morreale, (ed.). Madrid: CSIC. Justa (1674). Justa poética, lid de ingenios y celebrada academia en la Real Fábrica de Tabaco. Granada: Imprenta Real, por Nicolás Antonio Sánchez.

King, Willard F. (1967). Prosa novelística y academias literarias en el siglo XVII. Madrid: Real Academia Española.

Laird, Paul (dir.) [2008]. International Inventory of Villancico Texts [en línea]. [Ref. de 14 de junio de 2008] <http://www.sun.rhbnc.ac.uk/Music/ILM/IIVT/>.

León Marchante, Manuel de (1733). Obras poéticas póstumas... Tomo segundo. Madrid: Gabriel del Barrio.

Letras [1666]. Letras de los villancicos de Navidad, que han de cantar en la Santa Iglesia de Toledo Primada de las Españas, este año de 1666. Toledo: Francisco Calvo.

Letras [1667]. Letras de los villancicos de Navidad, que se han de cantar en la Santa Iglesia de Toledo Primada de las Españas, este año de 1667. Toledo: Francisco Calvo.

Letras [1694]. Letras de los villancicos que se han de cantar en la Iglesia Parroquial de señor S. Mateo de esta ciudad de Lucena. En la kalenda, noche y días del nacimiento de N. S. Jesu Cristo, este año de 1694. Puestos en música por D. Antonio Montoro Fernández de Mora. Córdoba: Diego de Valverde y Leyva y Acisclo Cortés de Ribera.

Letras [¿1695?]. Letras de los villancicos de la Virgen María Sacratísima del Rosario, cuya Hermandad las dedica a la muy ilustre y venerable Hermandad de la Santa Caridad, por mano del Hermano Mayor don Manuel Núñez de Silva. [s. 1.: s. i.].

Lohner, Tobías (1698). Instructissima Bibliotheca manualis concionatoria. Augustae Vindelicorum et Dilingae: Sumptibus Ioannis Caspari Bencard.

López de Mendoza, Antonio [1679]. Sacra relación panegírica de la fiesta que celebró... Granada, día del Corpus, año de 1679. Granada: Raimundo de Velasco.

López-Huertas Pérez, M. ${ }^{a}$ José (1997). Bibliografía de impresos granadinos de los siglos XVII y XVIII. Granada: Universidad de Granada.

Madroñal Durán, Abraham (2005). De grado y de gracias. Vejámenes universitarios de los Siglos de Oro. Madrid: CSIC.

Mas i Usó, Pasqual (1996). Academias literarias en la Valencia barroca. Kassel: Reichenberger.

Morales, Salvador de (1660). Descripción de la fiesta y los altares que... Granada hace en la fiesta del Santísimo Sacramento... Con los pensamientos y declaraciones dellos, con lugares de Escritura y versos. Granada: Imprenta Real, por Francisco Sánchez.

Morales, Salvador de (1661). Descripción de la fiesta y los altares que... Granada hace en la fiesta del Santísimo Sacramento... Granada: Imprenta Real, por Francisco Sánchez.

Morales, Salvador de (1662). Descripción de la fiesta y los altares que... Granada hace en la fiesta del Santísimo Sacramento..., con los pensamientos y declaración de los lugares de Escritura y versos. Granada: Imprenta Real por Francisco Sánchez.

Morales, Salvador de (1664). Adorno de la Plaza de Vivarrambla en el día que... Granada celebra su fiesta al Santísimo Sacramento, con la explicación de pinturas, heroglíficos y versos. Granada: Imprenta Real de Baltasar de Bolibar. 
Morales, Salvador de (1665a). Adorno de la Plaza de Vivarrambla, en el día que... Granada celebra su fiesta al Santísimo Sacramento, con la declaración de pinturas, heroglíficos y versos. Granada: Imprenta Real de Francisco Sánchez.

Morales, Salvador de (1665b). Descripción de la fiesta y de los altares que... Granada hace en la fiesta del Santísimo Sacramento..., con los pensamientos y lugares de Escritura. Granada: Imprenta Real de Francisco Sánchez.

Morales, Salvador de [1666]. Descripción de la fiesta y los altares que... Granada hace en la fiesta del Santísimo Sacramento en el día de san Juan Bautista, en que se celebra, con los pensamientos, lugares de Escritura y versos... Año de 1666. Granada: Imprenta Real de Francisco Sánchez.

Osuna, Inmaculada (2004a). «Aproximación a las academias granadinas del siglo XVII», en María Luisa Lobato y Francisco Domínguez Matito (eds.), Memoria de la palabra. Actas del VI Congreso de la Asociación Internacional Siglo de Oro (A.I.S.O.). Madrid: Iberoamericana / Vervuert, vol. II, pp. 1401-1409.

Osuna, Inmaculada (2004b). «Justas poéticas en Granada en el siglo XVII: materiales para su estudio». Criticón, 90, pp. 35-77.

Pérez de Montoro, José (1736). Obras póstumas líricas sagradas. Madrid: Antón Marín.

Ruiz de Elvira, Isabel (coord.) (1992). Catálogo de villancicos de la Biblioteca Nacional. Siglo XVII. Madrid: Biblioteca Nacional.

Sánchez, José (1961). Academias literarias del Siglo de Oro español. Madrid: Gredos.

Tejerizo Robles, Germán (1989). Villancicos Barrocos en la Capilla Real de Granada. 500 Letrillas cantadas la noche de Navidad (1673 a 1830). Sevilla: Junta de Andalucía.

Torrente, Álvaro y Janet Hathaway (2007). Pliegos de villancicos en la Hispanic Society of America y la New York Public Library. Kassel: Reichenberger.

Torrente, Álvaro y Miguel Ángel Marín (2000). Pliegos de villancicos en la British Library (Londres) y la University Library (Cambridge). Kassel: Reichenberger.

Trillo y Figueroa, Francisco de [1661]. Panegírico sacro en la fiesta que celebró... Granada, día del Corpus. Año de 1661. Granada: Baltasar de Bolíbar [también Granada: Imprenta Real por Francisco Sánchez, 1661].

Trillo y Figueroa, Francisco de (1672). Carta y relación de la fiesta del Santísimo Sacramento que celebró... Granada, año 1672. Granada: Imprenta Real de Francisco Sánchez.

Trillo y Figueroa, Francisco de (1951). Obras. Antonio Gallego Morell (ed.). Madrid: CSIC.

Vella, Juan Antonio de la [1661]. Carta en respuesta de otra de don Bartolomé de Vitoria, en que me pide le haga relación de la fiesta que... Granada celebró al Santísimo Sacramento, en este año de 1661, siendo comisarios don Juan de Vitoria, su hermano, y otros Caballeros Diputados. Granada: Baltasar de Bolíbar.

Vesselínova Pavlova, Pavlina (2004). «Voces desafinadas: sobre los extranjeros en el teatro breve del siglo XVII», en María Luisa Lobato y Francisco Domínguez Matito (eds.), Memoria de la palabra. Actas del VI Congreso de la Asociación Internacional Siglo de Oro (A.I.S.O.). Madrid: Iberoamericana / Vervuert, vol. II, pp. 1811-1817.

Villancicos [1666]. Villancicos que se han de cantar en la Santa Iglesia Magistral de S. Justo y Pastor de Alcalá de Henares, en los Maitines de Navidad, este año 1666, siendo Maestro de Capilla el Maestro Antonio García. [s. 1.: s. i.].

Villancicos [1684]. Villancicos que se han de cantar en los Maitines de los Santos Reyes en el Real Convento de la Encarnación este año de 1684. Siendo Maestro de Capilla el Licenciado Don Francisco Sanz. Madrid: Antonio de Zafra.

Fecha de recepción: 24 de noviembre de 2009

Fecha de aceptación: 5 de junio de 2010 